DIW BERLIN

Discussion

Papers
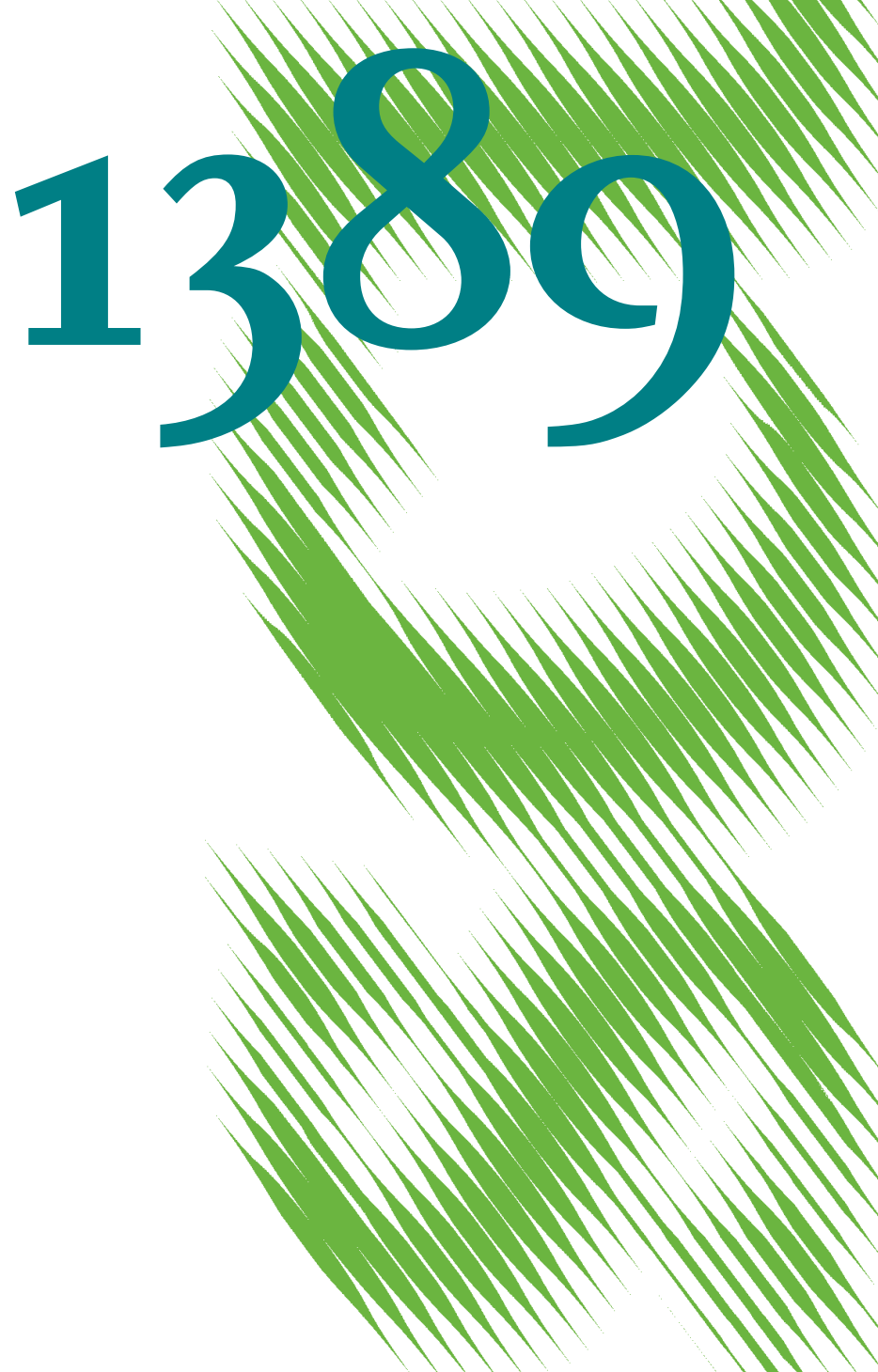

Rates of Return and

Early Retirement Disincentives

Evidence from a German Pension Reform 
Opinions expressed in this paper are those of the author(s) and do not necessarily reflect views of the institute.

IMPRESSUM

(C) DIW Berlin, 2014

DIW Berlin

German Institute for Economic Research

Mohrenstr. 58

10117 Berlin

Tel. $+49(30) 89789-0$

Fax +49 (30) $89789-200$

http://www.diw.de

ISSN 1619-4535

Papers can be downloaded free of charge from the DIW Berlin website:

http://www.diw.de/discussionpapers

Discussion Papers of DIW Berlin are indexed in RePEc and SSRN:

http://ideas.repec.org/s/diw/diwwpp.html

http://www.ssrn.com/link/DIW-Berlin-German-Inst-Econ-Res.html 


\title{
Rates of Return and Early Retirement Disincentives: Evidence from a German Pension Reform
}

\author{
Holger Lüthen \\ DIW Berlin and Freie Universität Berlin \\ (hluethen@diw.de)
}

May 2014

\begin{abstract}
To counteract the financial pressure emerging in aging societies, statutory pay-as-you-go pension schemes are undergoing fundamental reforms in many Western countries. Starting with cohort 1937, Germany introduced permanent pension deductions for early retirement. This paper examines the evolution of the profitability of pension contributions against the background of this reform for cohorts 1935-1945. I measure the profitability with the internal rate of return (IRR) and use high quality administrative data. For men the IRR declines from $2.4 \%$ to $1.2 \%$ and for women from $5.2 \%$ to $3.7 \%$. The results suggest that the deductions introduced by the reform only cause some part of this trend. The majority of the trend, about $75 \%-80 \%$, is caused by increased pension contributions.

JEL CODES: D02, D04, D14, D91, H55

Keywords: Pensions, reform, early retirement, disincentives, pay-as-you-go, rates of return, Germany
\end{abstract}

Acknowledgement: I thank Giacomo Corneo for his valuable advice and Peter Haan, Timm Bönke, Carsten Schröder, Daniel Kemptner, Ronny Freier, Adam Leder and the participants of various venues for helpful comments. 


\section{Introduction}

Aging populations challenge the solvency of public pension systems in most modern welfare states. Many governments plan or respond with reforms that cut pensions, elevate the minimum retirement age or incentivize individuals to stay longer in the labor market. In Europe, many states opted for a variety of reforms, with many major reforms passed after the early 1990 's. ${ }^{1}$ A pioneering country is Germany, which announced a reform introducing permanent pension reductions for early retirement in $1992 .^{2}$

I analyze the rates of return on pension contributions in Germany against the background of this reform. Similar to many other welfare states, Germany has a Bismarckian pay-as-you-go (PAYG) pension system with a strong link between pensions and prior contributions. Thus, rates of return can serve as an indicator for the performance of the system. Evaluating pension reform effects on the rates of return can help to assess potential changes in citizens' attitudes towards the pension scheme. If reforms are too vigorous, they lower a PAYG-system's social acceptance and decrease the contribution base due to a decline in voluntary contributions and an increase in evasive behavior (Börsch-Supan and Reil-Held, 2001; Schnabel, 1998). This can initiate a downward spiral. When evaluating a reforms' potential to cause such effects, it is necessary to document how well the pension system fares against alternative forms of investment like government bonds - both in general and post-reform. For such a comparison the rates of return on pension contributions are needed. Rates of return are also interesting per se. Contributors want to know if the returns exceed inflation rates and/or if they are likely to do so in the future. Apart from fairness aspects, a low profitability always fuels discussions about privately defined or capital funded pension plans and indicates potential increases in the old-age poverty risk. Considering reform evaluations, effects on the rates of return are therefore important information for policymakers.

The reform is gradually introduced for all cohorts born in 1937 and thereafter, exogenously determined by month and year of birth. Its potential effects are numerous. Hanel (2010) finds the reform to cause an average ten-month postponement in employment exit for the overall population. For employed men Bönke et al. (2014) find the reform to cause a 5.2-month postponement. The literature examining the relationship between retirement age and future pensions in an option-value framework (e. g. Stock and Wise, 1990; Börsch-Supan, 1992) also predicts a postponement. This view is shared by studies about the link between benefit-generosity and retirement timing (e. g. Börsch-

\footnotetext{
${ }^{1}$ Gruber and Wise (2007) provide an overview of recent reforms in OECD countries.

${ }^{2}$ Since retirement reforms usually take many years to be fully implemented, appropriate post reform data is often not available for many years. Therefore the literature on the evaluation of these reforms is only recently growing - with a focus on labor market effects (e.g. Mastrobouni (2009); Staubli and Zweimüller (2013); Haan and Prowse (2014); Laun and Wallenius (201X); Bönke et al. (2014)).
} 
Supan and Schnabel, 1998; Liebman et al., 2009). The reform could also affect employment through the intensity of job-search before retirement (Hairault et al., 2010), resulting in extended periods of work and greater contributions. In addition the reform could influence the likelihood of invalidity retirement (Riphan, 1999).

To measure the profitability of pension contributions I apply the concept of internal rates of return (IRR), which is also suited to evaluate reform effects. The IRR can be seen as an interest rate on the contributions that is sufficient to generate enough funds to return the pensions until the (statistical) death of the individual. Thus a higher IRR implies c. p. higher pensions. The approach condenses the profitability of pension contributions into a single number, allowing easy comparisons between distinctive groups like cohorts and sexes in different scenarios. I use individual level micro data and analyze the rates of return in two dimensions. In the intra-cohort dimension individual profitability comparisons reveal how the pension system treats insurants relative to each other (e. g. men versus women). In the inter-cohort dimension those comparisons serve as evidence on the relative treatment of cohorts and lifetime redistribution through the pension system (Liebman, 2002; Schröder, 2011). Redistributive elements of PAYG-systems feature e. g. a redistribution from low to high life-expectancy and from singles to married couples in case of survivor-benefits.

There are not many studies on the individual IRR of pension systems. Especially those with microdata are extremely rare. Notable exceptions are Gustman and Steinmeier (2001) and Liebman (2002), who look at redistributional effects of the US social security system. The only micro-data study on Germany is Schröder (2011), who looks at the IRR of cohorts 1940-1945 if and only if they retire in 2005. ${ }^{3}$ Hence the cohorts are included at a different age, preventing an inter-cohort comparison or a reform evaluation. For Germany most other studies on the IRR and its evolution are based on extrapolations using stylized biographies (Schnabel, 1998; Ohnsmann and Stolz, 2004; Schnabel and Ottnand, 2008). However, selected earnings paths of hypothetical workers are not necessarily representative for the population (Bosworth et al., 2000). In addition, the pension reductions introduced by the reform vary by retirement type. Therefore individual selection into retirement types could be affected by the reform, which is currently not modeled by studies using hypothetical biographies.

The underlying dataset of this study, the Insurance Account Sample (Versicherungskontenstichprobe, VSKT), includes complete insurance biographies of the cohorts born between 1935 and 1945. It can

\footnotetext{
${ }^{3}$ The requirements on datasets for answering IRR-related questions are high. For an exact calculation of the IRR, lifelong employment biographies as well as the entire acquired pension entitlements are needed. Those typically deviate from the mere entitlements gained through labor (for an overview see Börsch-Supan and ReilHeld, 2001).
} 
address both the inter- and the intra-cohort dimension and does not suffer from the representation issues of hypothetical biographies.

The results from the intra-cohort dimension reveal that women have a higher IRR due to their greater life-expectancy and because the pension system redistributes toward them. In the intercohort dimension the results suggest a decrease of the real IRR for men from $2.4 \%$ to $1.19 \%$ and for women from $5.15 \%$ to $3.72 \%$ over the 1935 to 1945 cohorts. The reform does not solely cause the negative trend; a larger share is caused by increases in contributions rather than by lowered pensions. The outcomes indicate a potential increase in the old-age poverty risk for younger and subsequent cohorts if private pensions fail do provide nationwide coverage. Regarding the social acceptance of the pension scheme, the considered cohorts do not experience negative rates.

The paper is structured as follows: Section 2 describes the dataset, the pension system and the reform. Section 3 explains the methodological framework. Section 4 provides the results of both the IRR and the reform effect. Section 5 looks at the overall development of pensions and contributions. Section 6 concludes.

\section{Data and institutional background}

\subsection{Data and sample}

The German pension insurance records individual insurance accounts, which contain monthly information on inter alia (un-)employment, sick-pay and pension contributions from age 14 up to a maximum of age 65. I use several waves of a sample of these biographies, the scientific use-files (SUF) of the Insurance Account Sample (Versicherungskontenstichprobe, VSKT). A SUFVSKT is a process produced stratified random sample of mandatorily insured individuals and contains about 60,000 observations each. Individuals are included if they are between 30 and 67 years of age in the reference year. Of those I select cohorts aged 66 or 67 (Table 1). ${ }^{4}$ The employment biographies are predominantly consistently documented and, due to their administrative nature, virtually free of measurement errors (Bönke et al., 2015).

The sample is restricted to native West Germans. Contributions of East Germans before the reunification are not comparable to those of West Germans. Further, persons with distinctive pension systems like miners, civil-servants and the self-employed are excluded as well as individuals without contributions or with more than 300 months of missing data (less than 5 years of information) in the main employment phase between 30 and 60; they do not offer enough

\footnotetext{
${ }^{4}$ For younger cohorts it is impossible to distinguish between old-age and invalidity pensions after the $60^{\text {th }}$ birthday.
} 
information for an IRR calculation. More details on the sample selection are provided in Appendix A. As shown in Table 2, the final sample consists of about 260 men and 390 women per cohort, with 2,901 men and 4,268 women in total. ${ }^{5}$ The weighted values represent between $55 \%$ and $72 \%$ of the native West German population.

Table 1: Number of observations by sex and cohort

\begin{tabular}{|c|ccc|ccc|c|}
\hline \multirow{2}{*}{ Cohort } & \multicolumn{3}{|c|}{ Men } & \multicolumn{3}{|c|}{ Women } & Cohort origin* \\
\cline { 2 - 6 } & Unweighted & Weighted & Share** & Unweighted & Weighted & Share** & SUFSKT \\
\hline 1935 & 260 & 210,872 & 65.18 & 378 & 233,974 & 64.86 & 2002 \\
1936 & 262 & 221,736 & 65.56 & 387 & 241,651 & 64.65 & 2002 \\
1937 & 257 & 205,775 & 60.94 & 405 & 214,689 & 57.31 & 2004 \\
1938 & 254 & 231,066 & 64.75 & 362 & 217,792 & 55.04 & 2005 \\
1939 & 293 & 273,041 & 72.33 & 370 & 239,760 & 63.51 & 2006 \\
1940 & 262 & 257,736 & 67.85 & 389 & 238,617 & 56.92 & 2007 \\
1941 & 278 & 243,630 & 68.93 & 389 & 239,127 & 61.79 & 2008 \\
1942 & 262 & 184,504 & 62.36 & 391 & 191,068 & 59.98 & 2009 \\
1943 & 252 & 184,445 & 65.46 & 386 & 197,553 & 63.95 & 2009 \\
1944 & 252 & 183,131 & 63.53 & 410 & 225,081 & 72.30 & 2010 \\
1945 & 269 & 142,954 & 67.73 & 401 & 167,626 & 72.67 & 2011 \\
\hline & 2,901 & $2,338,890$ & & 4268 & $2,406,938$ & & \\
\hline
\end{tabular}

* This column states the origin dataset of the respective cohort. Each observation contains a complete individual biography. **Share depicts of the number of weighted observations divided by the overall West German population (excluding Berlin). Source: SUFVSKT2002, 2004-2011 and Federal Statistical Office (2013), own calculations.

\subsection{Retirement in Germany}

The German statutory pension scheme offers various retirement possibilities depending on the retiree's individual situation. Since there is an old-age pension for women only, women and men have different pension prospects and are analyzed separately. The cohorts considered have access to five different types of old-age pensions:

1. The regular old-age pension that can be claimed after age 65;

2. The unemployment pension that is open after age 60 , but requires at least 52 weeks of unemployment after the age of 58.5. It is also open to applicants retiring through the law about part-time work for employees over 55. This law allows early retirement without unemployment for employees halving their working hours for at least 24 months after turning 55 (§ 237 in Bundesministerium der Justiz (BMJ), 2012);

3. The disability pension that can be claimed after 60 if a disability is diagnosed;

\footnotetext{
${ }^{5}$ The considered sample of West Germans is validated by Bönke et al. (2015), who conclude from a comparison with representative German survey-data from the SOEP that the VSKT is sufficiently representative for about $80 \%$ of the West German workforce. A direct comparison of the cohorts considered is not possible due to the small number of observations in comparable survey data. The lower number of unweighted men mainly stems from the exclusion of miners, who are predominantly males and oversampled in the SUFVSKT.
} 
4. The pension for long-term insured that is open to applicants after 63 and needs a waiting period of 35 years; $^{6}$

5. The old-age pension for women which can be chosen by women after turning 60 , but requires 120 months of compulsory contributions after their $40^{\text {th }}$ birthday. ${ }^{7}$

Each pension type requires a different length of the waiting period, which is the number of years spent in the pension system (see Table 2 below). Since the VSKT lacks information on the pension type, I determine the type through a combination of the exact age of old-age retirement, periods of unemployment, invalidity or sick pay and the waiting period. More details and comparisons of sample and official population data (VDR, 2004) are provided in Appendix A.

\subsection{The 1992 pension reform}

The cohorts considered are partly affected by a major pension reform in 1992. The reform aimed to secure the German statutory pension system's financial basis. ${ }^{8}$ In addition to several -for the considered cohorts minor-changes, the reform introduces permanent pension deductions for early retirement compared to the previous/regular level. ${ }^{9}$ After the reform, pensions are lowered by $0.3 \%$ times the number of month retiring before age 65 (63 for disabled individuals, Figure 1 and Table 2). The deductions are phased in and start at one month respectively $0.3 \%$ for persons born in January 1937 for certain retirement types. They increase for later born individuals by $0.3 \%$ per month up to a particular maximum depending on eligibility age and retirement type. The penalty level during phasein is determined by the distance (in month times $0.3 \%$ ) between the actual retirement age and the (type- and date of birth-specific) retirement age without deductions. The eligibility ages are not affected by the reform. After the reform is fully implemented, the maximal penalty amounts to $7.2 \%$ for long-term insured, $10.8 \%$ for disability and invalidity and $18 \%$ for unemployed and women. Figure 1 shows the minimum deduction-free retirement age depending on year and month of birth.

\footnotetext{
${ }^{6}$ Waiting periods of 5, 10 and 15 years consist of contribution periods, periods of wage replacement benefits (unemployment, sick-pay) and periods of child-raising. Waiting periods of 35 years additionally include times of education or invalidity (§§ 50- 62 in BMJ, 2012).

${ }^{7}$ Periods of compulsory contributions consist of contribution periods, periods wage-replacement benefits (unemployment, sick-pay) and periods of child-raising (§55 in BMJ, 2012).

${ }^{8}$ The reform was originally passed into law only two hours before the Berlin Wall fell in 1989. Thus, further reforms and adjustments were needed during reunification process (Schmähl, 2011). A clear deduction of each reform step/adjustment is not possible due to partial overlap. Therefore I carefully explain the deduction system and speak of "the reform" in the following, meaning the reform in 1992 and follow-ups.

${ }^{9}$ The reform also introduces a bonus of $0.5 \%$ per month for delaying retirement past 65 in combination with the regular old-age retirement. Since only a negligible number of people claim this bonus, it is not expanded upon here. Still it is included in the calculations.
} 
Figure 1: Retirement age without deductions by pension type and year and month of birth

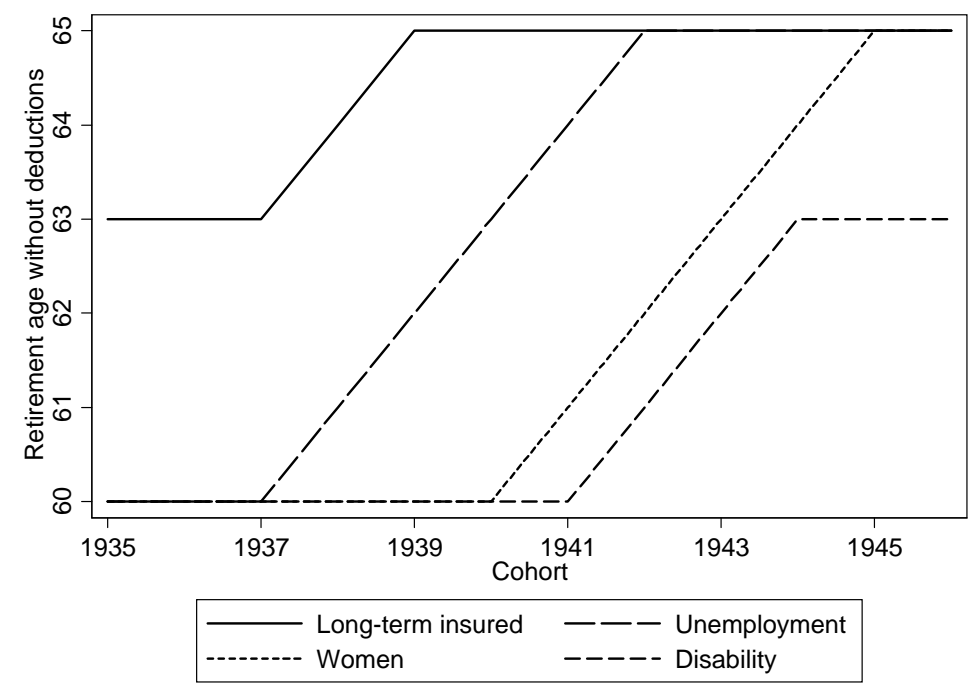

Source: BMJ (2012), own calculations.

The reform also introduces a non-old-age pension, the invalidity pension. It took effect in 2001 and is split into two types, full (100\%) and partial (50\%). The share of full invalidity pensioners amounts to about $80 \%$ (DRV, 2011). ${ }^{10}$ Invalidity pensions are deducted by $0.3 \%$ per month if retiring before 63 , up to a maximum of $10.8 \%$. The pensions are granted to about $20 \%$ of all retirees (DRV, 2013). The applicants have to be younger than 65 and unable to work for more than 3 hours (full) or 3 to 6 hours (partial) during the time they receive the pension. It is possible to end an invalidity pension and return to the labor market, but this is not common. An overview about the post-reform state for all types of pension is given in Table 2. Deductions did not exist pre-reform. Still, there is evidence that the deductions are not "fair" and should be higher (Breyer and Hupfeld, 2010).

\footnotetext{
${ }^{10}$ The full invalidity pension replaces the general disability pension (full pension) and the partial invalidity pension replaces the occupational disability pension ( $2 / 3$ of the pension amount).The ratio of $80 \%$ holds also for general in relation to occupational disability pensioners (Riphahn, 1999). When speaking of invalidity pensions in the following, its predecessors of general and occupational disability are meant as well.
} 
Table 2: Pension types in the post-reform state

\begin{tabular}{|l|c|c|c|c|c|}
\hline Pension type & $\begin{array}{c}\text { Eligibility } \\
\text { age }\end{array}$ & $\begin{array}{c}\text { Years in pension } \\
\text { system required } \\
\text { (waiting period) }\end{array}$ & $\begin{array}{c}\text { Deductions } \\
\text { before age }\end{array}$ & $\begin{array}{c}\text { Maximal } \\
\text { deduction }\end{array}$ & $\begin{array}{c}\text { Cohort } \\
\text { affected } \\
\text { first }\end{array}$ \\
\hline Regular old-age (§ 235) & 65 & 5 & $-*$ & $-^{*}$ & $-^{*}$ \\
Long-term insured (§ 236) & 63 & 35 & 65 & $7.2 \%$ & 1937 \\
Unemployment (§ 237) & 60 & 15 & 65 & $18 \%$ & 1937 \\
Women (§ 237a) & 60 & 15 & 65 & $18 \%$ & 1940 \\
Disability (\$236a) & 60 & $35^{* *}$ & 63 & $10.8 \%$ & 1941 \\
\hline Invalidity (\$§ 240, 241) & $-* * *$ & 5 & 63 & $10.8 \%$ & \\
\hline
\end{tabular}

*The regular old-age can be claimed only after turning 65 . Deductions are not envisaged in this pension type.

**In case of disability due to an occupational injury, the waiting period is prematurely fulfilled (§53 BMJ, 2012).

***There is no eligibility age for the invalidity pension. It requires 36 month of compulsory contributions instead.

Source: BMJ (2012), own calculations.

Over the course the reform, the retirement age rises. Figure 2 shows the average old-age retirement age by cohort, showing an increase in the retirement age of the regarded cohorts by about 5 month.

Figure 2: Average retirement in West Germany by cohorts, official and sample

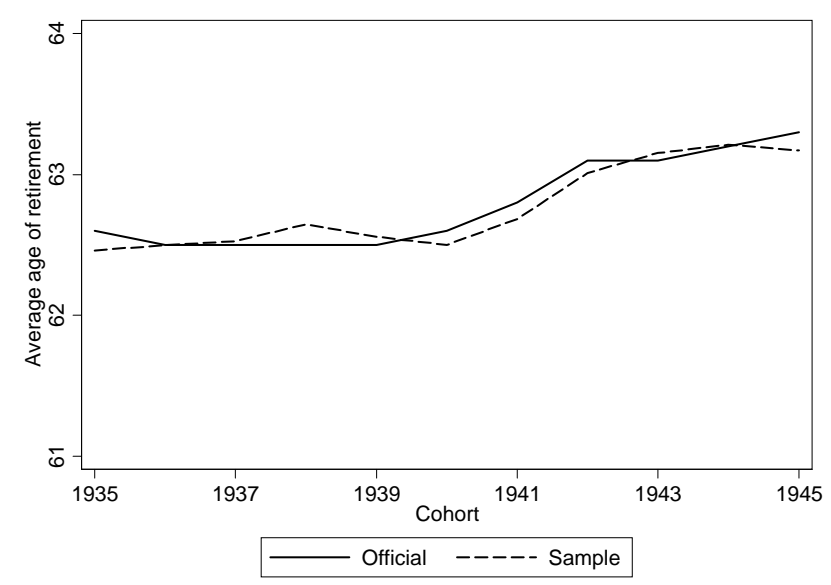

Source: DRV (2013) [official] and SUFVSKT2002, 2004-2011 [sample], own calculations using weighted data.

\subsection{Pension entitlements and earnings points}

The annual pension, $p_{j, t}$, is determined by the pension formula ( $\S 64, \mathrm{BMJ}, 2012$ ):

$$
p_{j, t}=m_{t} \cdot A_{t} \cdot R A_{j} \cdot Z_{j} \cdot E P_{j}
$$

where $m_{t}$ depicts the number of months the pension was received in the respective year. For old-age pensions, $m_{t}$ always equals 12 in every year except the first year. $A_{t}$ denotes the current pension value (e. g. $27.20 €$ in 2010). The pension value is determined by various factors: the average wage, the contribution rate, the demographic development and the Riester-Faktor (§68, BMJ, 2012). The Riester-Faktor lowers the pension value growth to limit the future contribution rate growth. The legislator expects investments in private pension schemes to compensate the lower statutory pensions (Clemens, 2011). $R A_{j}$ depends on the pension type. It is 1 for old-age and full invalidity pensions and 0.5 for partial invalidity pensions ( $2 / 3$ before 2001). $Z_{j}$, the age factor, is introduced by 
the reform and contains the potential deductions due to early retirement. $E P_{j}$ represents the sum of the collected earnings points (EP). An EP is based on individual pension contributions divided by the average social security earnings in the respective year. ${ }^{11}$

Not all earnings points stem from own contributions; periods of child raising, education, and invalidity also increase the total number of EP. Those points can be credited in retrospect, so that the period of origin is not always discernible. Börsch-Supan and Reil-Held (2001) provide many details about these so called transfer points and find that they are decreasing for younger cohorts. Divorces also affect the EP, because the economically stronger partner has to transfer some of his/her earnings points to the weaker partner. ${ }^{12}$ Table (3) provides the sum of EP and transfer points by gender and cohort. On average, men acquired more EP than women, whereas women acquired more transfer points. The larger share of transfer points for woman causes, ceteris paribus, a higher IRR. There is no distinctive trend in transfer points or sum of EP for men, whereas women experience a slightly u-shaped development and a decline in the transfer points share. Thus the effect of transfer points on the IRR is likely to be time invariant for men while it is slightly decreasing for women.

Table 3: Average sum of earnings points and transfer points share by cohort and sex

\begin{tabular}{|c|ccc|ccc|}
\hline & \multicolumn{3}{|c|}{ Men } & \multicolumn{3}{c|}{ Women } \\
\hline Cohort & $\begin{array}{c}\text { Sum of } \\
\text { earnings points }\end{array}$ & $\begin{array}{c}\text { Transfer } \\
\text { points* }\end{array}$ & $\begin{array}{c}\text { Transfer } \\
\text { points share }\end{array}$ & $\begin{array}{c}\text { Sum of } \\
\text { earnings points }\end{array}$ & $\begin{array}{c}\text { Transfer } \\
\text { points* }\end{array}$ & $\begin{array}{c}\text { Transfer } \\
\text { points share }\end{array}$ \\
\hline 1935 & 47.97 & 4.09 & 8.53 & 20.98 & 7.24 & 34.54 \\
1936 & 48.34 & 5.18 & 10.72 & 21.36 & 7.18 & 33.61 \\
1937 & 48.16 & 3.90 & 8.09 & 19.43 & 6.32 & 32.52 \\
1938 & 47.63 & 3.93 & 8.24 & 19.30 & 5.52 & 28.61 \\
1939 & 47.91 & 3.76 & 7.84 & 19.68 & 5.91 & 30.02 \\
1940 & 49.20 & 3.79 & 7.71 & 20.36 & 5.34 & 26.23 \\
1941 & 48.18 & 3.90 & 8.09 & 21.48 & 6.09 & 28.33 \\
1942 & 50.32 & 4.67 & 9.27 & 21.11 & 6.06 & 28.68 \\
1943 & 49.61 & 3.80 & 7.65 & 21.95 & 6.07 & 27.66 \\
1944 & 47.30 & 3.68 & 7.78 & 21.42 & 6.35 & 29.66 \\
1945 & 48.80 & 4.22 & 8.66 & 21.96 & 6.27 & 28.53 \\
\hline
\end{tabular}

*Transfer points depict the difference between the actual amount of earnings points and the amount earned through labor. Source: SUFVSKT2002, 2004-2011, own calculations using weighted data.

\footnotetext{
${ }^{11}$ Invalidity pensions are calculated of the basis of hypothetical earnings points, which retirees would have earned if they could continue to work.

${ }^{12}$ The amount is determined as half of the EP difference of those points earned during the time of the marriage. Information about gains and losses due to divorces is included in the data. In the sample a woman receives on average $0.9 \mathrm{EP}$ and passes $0.014 \mathrm{EP}$, whereas a man receives on average $0.03 \mathrm{EP}$ and passes 0.87 EP. As divorces usually cause other investment forms to be split up, those points are neither subtracted nor returned. The effect of divorces is omitted in a robustness test in Appendix C. In general, gender differences in the number of transfer points are only partly caused by divorces. Times of child-rising get mainly credited to women, whereas men have longer periods of education.
} 


\section{Methodology}

The profitability of pension contributions is measured with the IRR. Intuitively, the approach computes an interest rate paid on the contributions, which is sufficient enough to pay out the stream of pensions received by an individual. The method assigns an interest rate to contributions and pensions equating both sides' net present values. Here it yields an interest rate $i$, that equalizes the sum of contributions $c$ and the expected value of pensions $p$ in the year of retirement $R$. In the following year $X$ represents the year an individual reaches age $X$. This has been chosen to simplify notation through independence of specific cohorts.

$$
\begin{aligned}
\sum_{a=\text { year } 14}^{R} c_{j, a} \gamma^{R-a} & \left(1+i_{j}\right)^{R-a} \\
& =\sum_{a=R}^{\text {year } 65} \frac{p_{j, a}}{\left(1+i_{j}\right)^{a-R} \gamma^{a-R}}+\sum_{a=\text { year } 66}^{\text {year } 100} \frac{\varphi_{v, a} p_{j, a}}{\left(1+i_{j}\right)^{a-R} \gamma^{a-R}}
\end{aligned}
$$

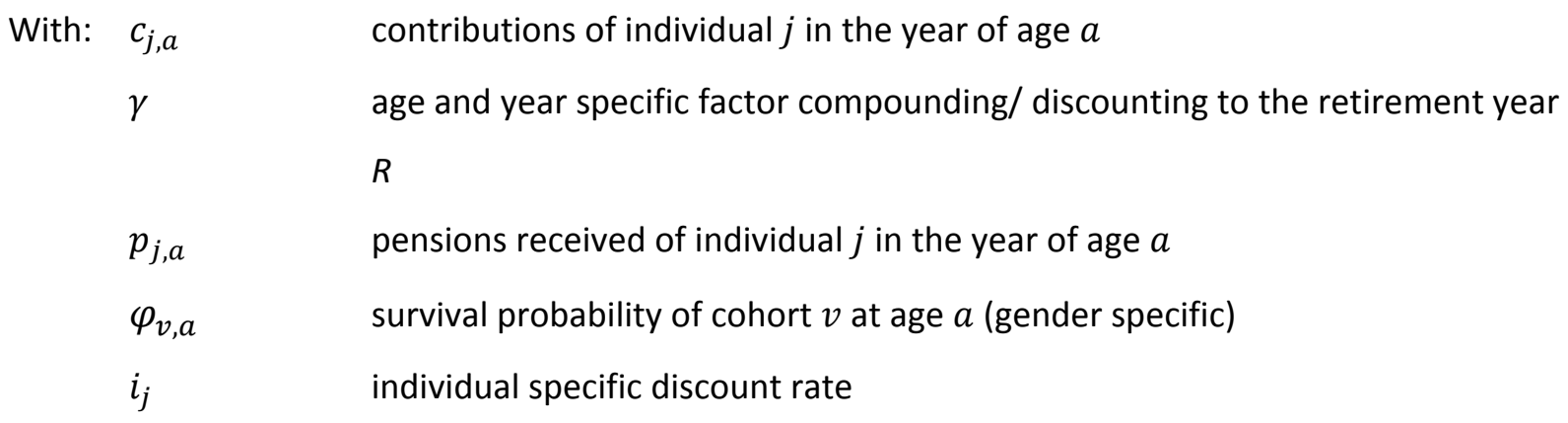
The left-hand side of Equation 2 contains the sum of contributions from the year the individual turns 14 until the retirement year $R$ (compounded to $R$ ). The right-hand side of Equation 2 depicts the pensions from $R$ to year 100 (discounted to $R$ ) and is split into two parts. The first term represents the sum of pensions ranging from $R$ to year65. The second term includes the pensions ranging from year66 to year100. Each pension in this term is multiplied with the survival probability $\varphi_{v, a}$, which constitutes the probability that the individual is still alive at age $a$ (conditional on the individual being alive at 65). The survival probabilities are sex and cohort specific for West Germans (Federal Statistical Office, 2011). Robustness checks considering differential mortality are based on Shkolnikov et al. (2008) and are shown in Appendix C, Figure C.1. The age and year specific discount factor $\gamma$ is based on the consumer price index. Contributions and pensions are real values to the base year $R .^{13}$

\footnotetext{
${ }^{13}$ Experiments with hyperbolic social discount rates according to Weitzman (2001) caused a parallel shift of the IRR by about -2.3 percentage points. Since the trend was not affected, these results are not discussed here.
} 
Each term in Equation 2 also includes the individual specific discount factor $i_{j}$ (the IRR), which balances both sides and is computed from the data.

There is one necessary extension to Equation 2. Since the pension insurance spends about $20 \%$ of its retirement expenses on widow(er) pensions (DRV 2013), those should be included in the IRR computations. In Germany, widow(er)'s benefits (§ 46, BMJ, 2012) ) $^{14}$ amount to $60 \%$ of the deceased partner's pension. An exact calculation requires information on the marital status and the partner's pension prospects. The VSKT lacks this information. Therefore, following Hanel (2010), cohort and gender specific marriage rates, $m_{v}$, are drawn from the SOEP (v27) for German natives. ${ }^{15}$ These marriage rates depict the probability of being married at the age of 65 . The partners' pension, $w_{v, a}$, is assumed to be the average pension of an individual of the same cohort and the other sex, multiplied with the likelihood of being deceased for that person. ${ }^{16}$ Hence, the total level of the widow(er)'s pension is based on 0.6 times the marriage probability $m_{v}$ times the pension level of a potential partner in case of her/his death $w_{v, a}$. The average earnings points underlying this calculation are drawn by sex and cohort before any individuals are excluded.

$$
\begin{aligned}
\sum_{a=\text { year14 }}^{R} c_{j, a} \gamma^{R-a} & \left(1+i_{j}\right)^{R-a} \\
& =\sum_{a=R}^{\text {year65 }} \frac{p_{j, a}}{\left(1+i_{j}\right)^{a-R} \gamma^{a-R}}+\sum_{a=\text { year66 }}^{\text {year } 100} \frac{\varphi_{v, a}\left(p_{j, a}+0.6 m_{v} w_{v, a}\right)}{\left(1+i_{j}\right)^{a-R} \gamma^{a-R}}
\end{aligned}
$$

The computation of equation 3 requires assumptions on the development of the future pension level. One approach is to leave the pension value constant after 2013 and assume a real pension growth of $0 \%$, which is done as a robustness check in Appendix C. A more realistic prediction needs forecasts of the gross wage replacement rate of pensions and the real wage growth (baseline scenario). For the replacement rate I rely on the "Niveausicherungsklausel" (§ 154, BMJ, 2012). Due to the demographic development, future rates are likely to decline and therefore the German legislature has set a minimum future rate. While the rate amounts to $50 \%$ in 2010 , the law allows a

\footnotetext{
${ }^{14}$ Here only the "major" widow(er)'s pension is regarded. Other survivor pensions, like the minor widow(er)'s pension, which starts before age 46 , and the orphans' pension cannot be modeled appropriately and are not considered.

${ }^{15}$ The SOEP is a highly representative annual household survey of the population living in Germany.

${ }^{16}$ The SOEP further reveals that men are about 2 years older in marriages of the considered cohorts. Since twoyear differences are not available for the all cohorts, the same cohorts are taken for consistency reasons. Empirical tests show that the earnings points differences between the cohorts (see Table 3 ) are too small to cause non negligible deviations. Figure C. 2 in Appendix C provides robustness checks for varying marriage rates of $0 \%$ and $100 \%$. Only minor level effects appear.
} 
decline to a minimum of $46 \%$ in 2020 and $43 \%$ in 2030 . I assume a gradual decline of the rate by $0.007 \%$, which leaves the rate just above the minimum required by the legislature. The pension values are allowed to decline further after $2030 .{ }^{17}$ For the real wage growth I assume an annual growth rate of $1.52 \%$, following the OECD (2012) projections until $2043 .{ }^{18}$ Both effects combined predict increasing real pensions until 2043. The employee and employer shares of contributions to the pension insurance are combined in these calculations. This means that employees carry the complete economic burden of social security contributions. ${ }^{19}$ For the computation, missing values in the contribution periods are replaced with zeros.

\section{Results}

Figure 3 shows the IRR development over the observed cohorts. ${ }^{20}$ The mean IRR drops from $2.4 \%$ to 1.19\% for men and from $5.15 \%$ to $3.72 \%$ for women (Fig. 3(a) and Fig. 3(b)). The differences between the sexes can be mainly ascribed to women's larger share of transfer points (see Table 2). The uneven distribution of transfer points also causes the more heterogeneous results of women (in line with Schröder, 2011). Variations are caused by e. g. divorces or the number of children. Some further differences are caused by their higher live expectancy ${ }^{21}$ and the favorable old-age pension for women (seized by about half of the women in the sample). ${ }^{22}$

In general the German statutory system insures against two types of risk, longevity and invalidity. For those who utilize both insurances a higher return is expected. Therefore the mean IRR of individuals who start their retirement with invalidity pensions are singled out in Figures 3(c) and 3(d). Both sexes start with a higher IRR and experience no visible trend over the cohorts. The higher IRR originates from shorter contribution and longer pension periods. In addition the most likely follow-up pension type is the disability pension, which has the smallest deductions of all pension types. However, the

\footnotetext{
${ }^{17}$ Holding the pension level constant after 2030 causes only minor deviations from the baseline results. These results are available from the author upon request.

${ }^{18}$ The rates stem from the labor efficiency trends. In long-term projections, it is assumed that wages follow labor productivity (European Commission 2005).

${ }^{19}$ This assumption is in line with the standard view about tax incidence. See Fullerton and Metcalf (2002) for an overview and Gruber (1999) for a validation through a natural experiment. However, the standard view has been recently challenged by Saez et al. (2012). Therefore, a robustness check without the employer's share is provided in Appendix $\mathrm{C}$ in order to provide an upper and a lower bound.

${ }^{20}$ Following Schröder (2011), individuals with the highest and the lowest IRR (symmetry) are excluded due to extreme outliers at the top. Here the results are censored at the $97.5 \%$ and the $2.5 \%$ level. For robustness I also consider two further scenarios with varying groups. One only considers complete biographies without missing information in the main employment phase between 30 and 60 . The other excludes persons with invalidity pensions. See Appendix $B$ for the respective numbers and the additional results. The trend is unaffected.

${ }^{21}$ The remaining life expectancy at the age of 65 amounts to e. g. 17.39 years for men and to 20.78 years for women born in 1935 (Federal Statistical Office, 2011).

22 See Appendix A for a comparison of old-age retirement type shares.
} 
DRV (2012) shows that invalidity pensioners are more affected by poverty risk than the average population and that invalidity pensions are the only income for the majority of invalidity pensioners.

Figure 3: IRR boxplots and means (dashed line) by sex and cohort, Scenario 1 [base] and 2 [only invalidity]

(a) Base (men)

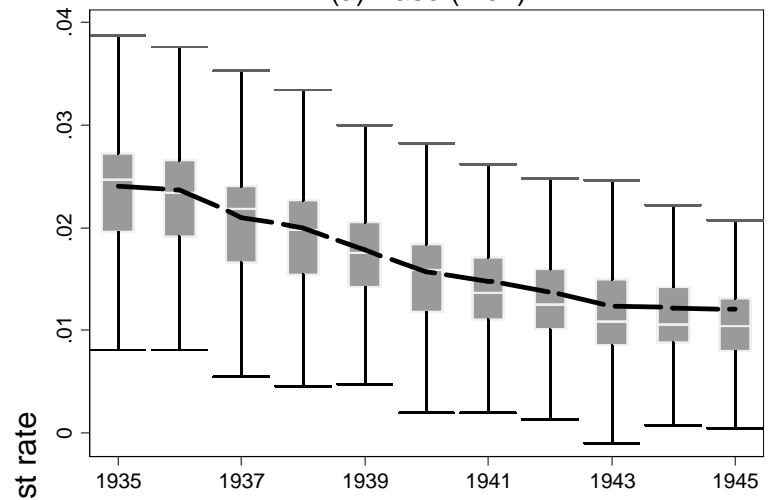

(c) Only invalidity (men)

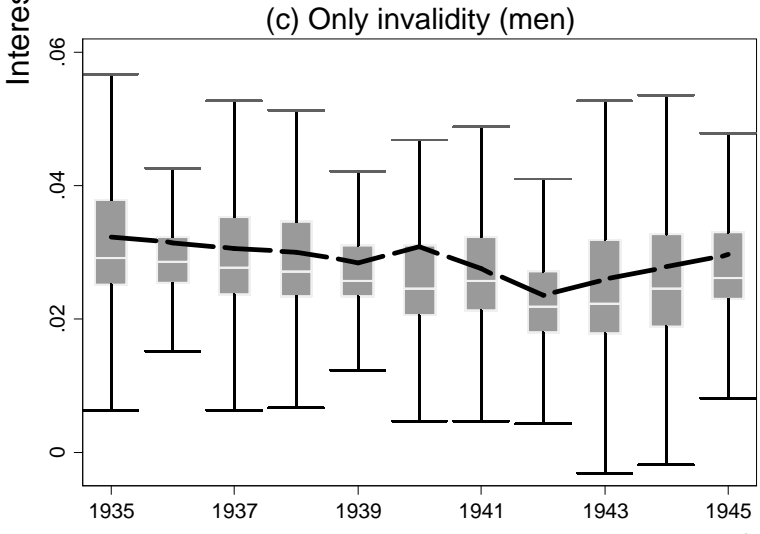

(b) Base (women)

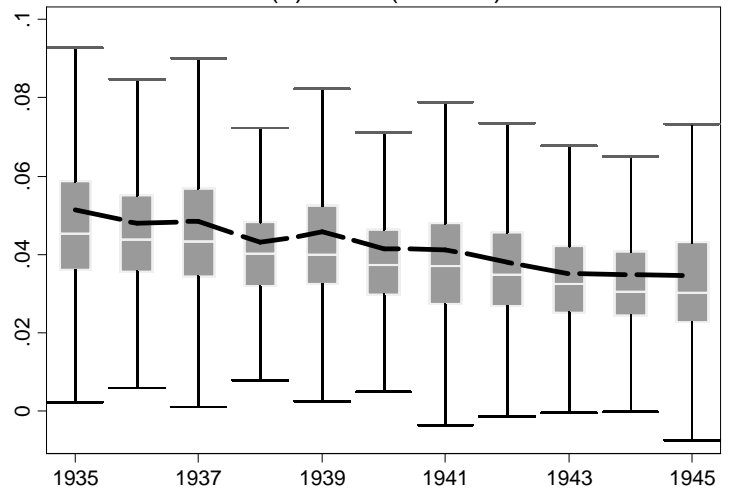

(d) Only invalidity (women)

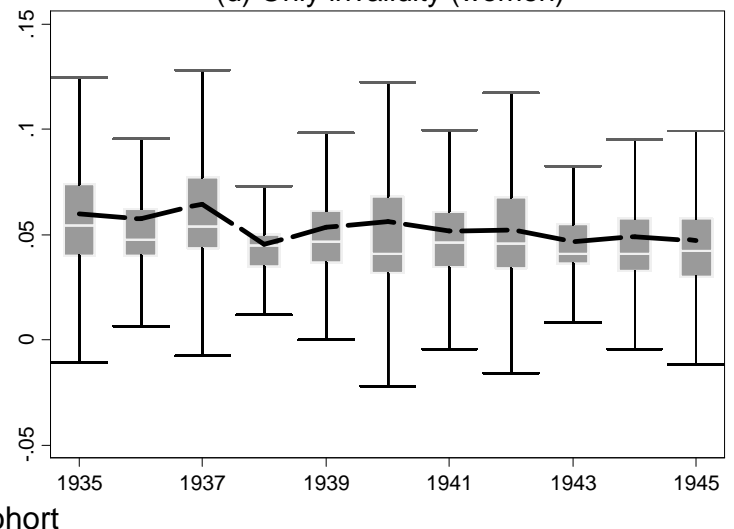

Note: The dashed line depicts the mean. Boxplot outliers are suppressed for reasons of clarity. Results are censored at the $2.5 \%$ and the $97.5 \%$ level.

Source: SUFVSKT2002, 2004-2011, own calculations.

It is now important to determine if the downward trend shown in Figures $3(a)$ and $3(b)$ is caused by the reform or if other factors played a role, too. To measure the reform effect I calculate two counterfactual scenarios (see Figure 4). Figure 4 (a) displays a comparison between the baseline scenario and a scenario without deductions, suppressing the reform effects. The phase-in of the reform for men born after 1937 and for women after 1939 is clearly visible (the old-age retirement for women is reformed only after 1939). The differences for the youngest cohorts amount to 0.2 percentage points for both sexes. This means that the direct reform effect causes $13 \%$ of the decline for women and $19 \%$ of the decline for men. Still, behavioral responses to the reform are likely to raise the retirement age due to a lower pension level (Figure 2 and e. g. Stock and Wise, 1990; Börsch-Supan, 1992; Hanel 2010), the intensity of job search before retirement (Hairault et al., 2010), the choice of the retirement type, the tradeoff between unemployment benefits and disability pension and/or the entry likelihood in invalidity pensions in general (Riphahn, 1999). Therefore, the direct effect is rather a lower bound of the reform impact. With a similar exercise I intend to measure 
the upper bound of the reform. Figure $4(\mathrm{~b})$ shows the differences between the baseline scenario and a situation which imposes the retirement deductions on all cohorts. The differences between the oldest cohorts' mean IRR under baseline condition and a situation under full reform should capture the reform effect without distortions through behavioral adjustments. The results suggest a difference of about 0.35 percentage points for both sexes, amounting to a reform effect of $20.1 \%$ for women and of $30 \%$ for men.

In order to examine the IRR development apart from the reform, Figure 4 (c) shows a counterfactual comparison where all cohorts are retired artificially at age 60 (without deductions). Therefore this scenario shows the time trend only. For the calculations earnings points collected after the $60^{\text {th }}$ birthday are subtracted and a hypothetical pension based on the earnings points earned up to age 60 is imputed. The differences between the 1935 and the 1945 cohort are about 1.14 percentage points for women and to 0.91 percentage points for men. The results are in line with those of Figures 4 (a) and 4 (b) and suggest that the time trend explains about $80.7 \%$ in the decline for women and about $75 \%$ in the decline for men.

Figure 4: IRR means by sex and cohort, counterfactuals with and without reform and artificial retirement at 60

(a) No reform

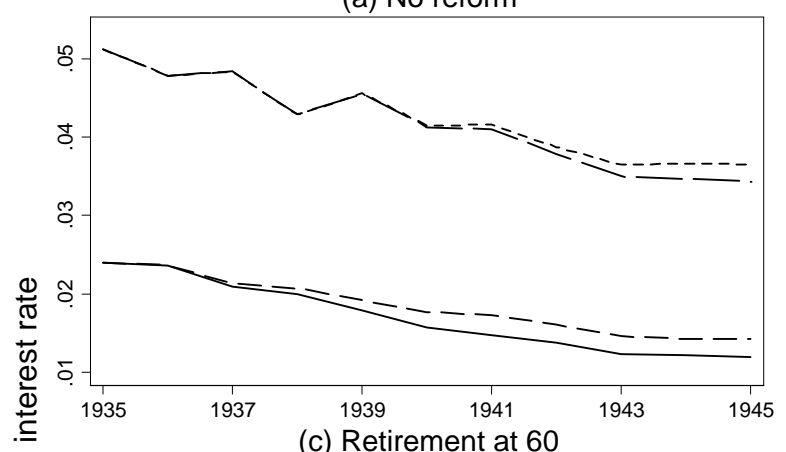

ฮั

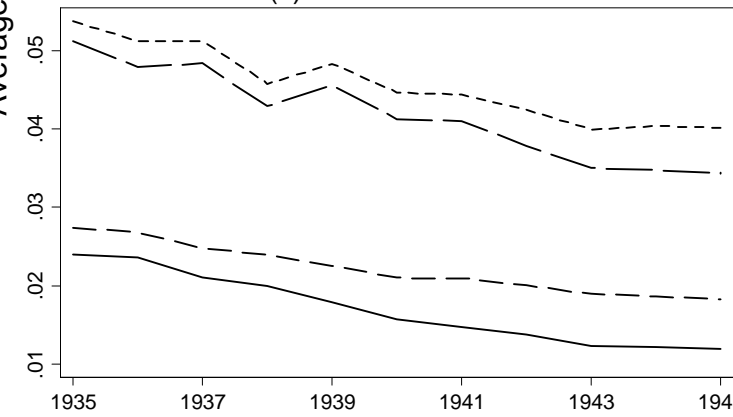

Cohort
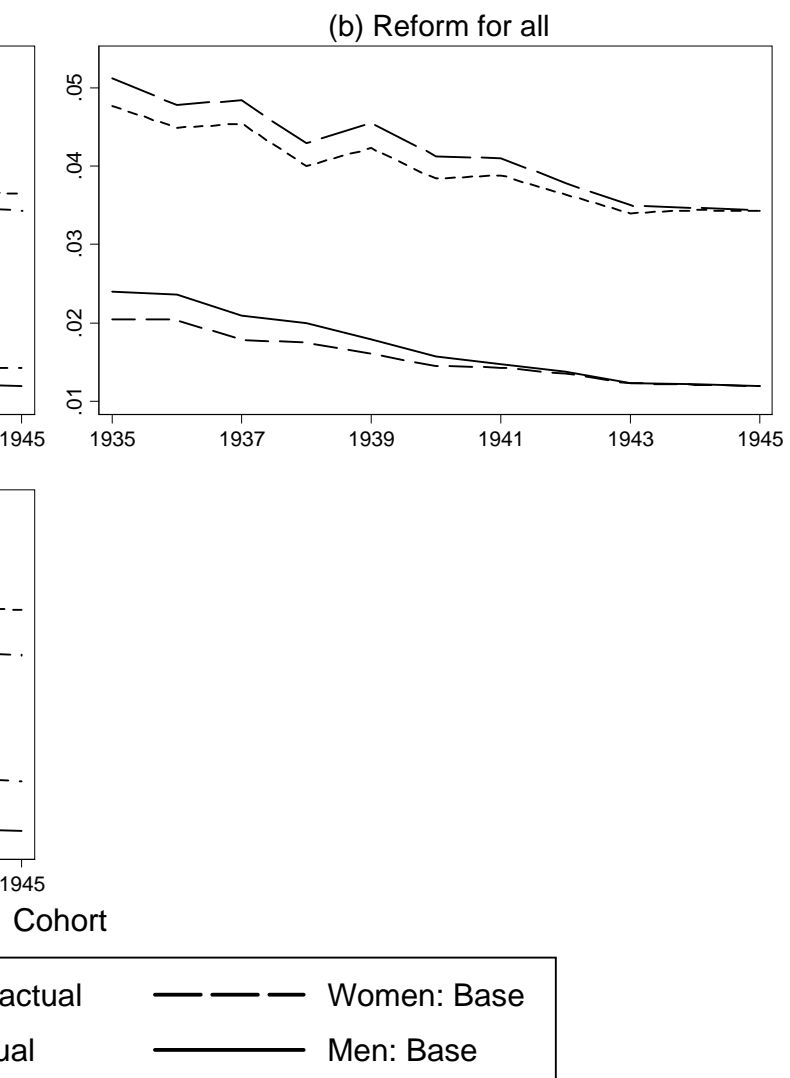

Source: SUFVSKT2002, 2004-2011, own calculations. 


\section{Explaining the time trend}

Since other changes to the pension scheme seem to cause a larger part of the IRR decline, this part sheds light on these developments. Figure 5 displays the NPVs of pensions and contributions, compounded/discounted to the year 2000 in real values. Figure 5 reveals a decline in the pension NPVs of men from $306,000 €$ to $286,000 €$. Without deductions their sum increases slightly to $309,000 €$. However younger cohorts tend to live longer, which causes the IRR of equal sums to be lower for younger cohorts because their pensions are stretched over a longer timeframe. In the present case, mortality differences are not suited for an explanation since life expectancies grew only about 1 month per cohort. ${ }^{23}$ For women the picture is slightly different. Their sum of pensions stays roughly constant and circles around $180,000 €$. Without reform there is a slight increase to 192,000 $€$. Figure 5 further depicts an increase in the sum of contributions, from $152,000 €$ to $199,000 €$ for men and from $48,000 €$ to $68,000 €$ for women. The relative changes in the sums of contributions are much larger than in the sums of the pensions, making it a likely explanation for a larger part of the declining IRR.

Figure 5: NPVs of pensions and contributions in year 2000 real values, means by sex and cohort

(a) Men

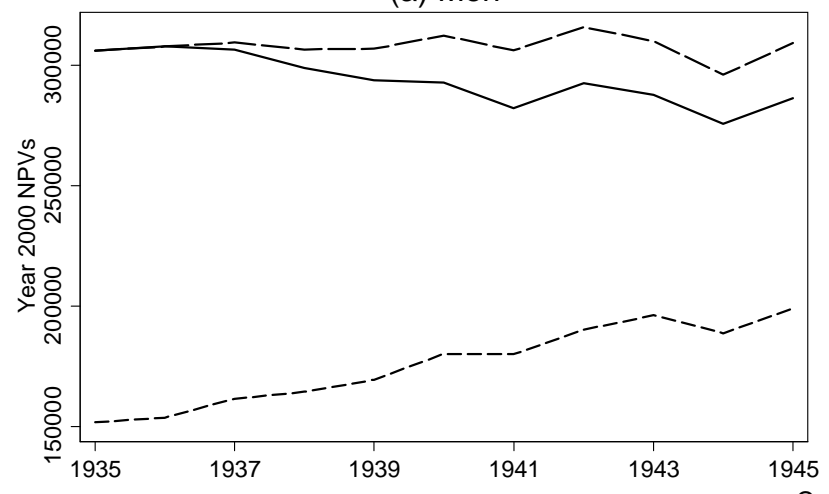

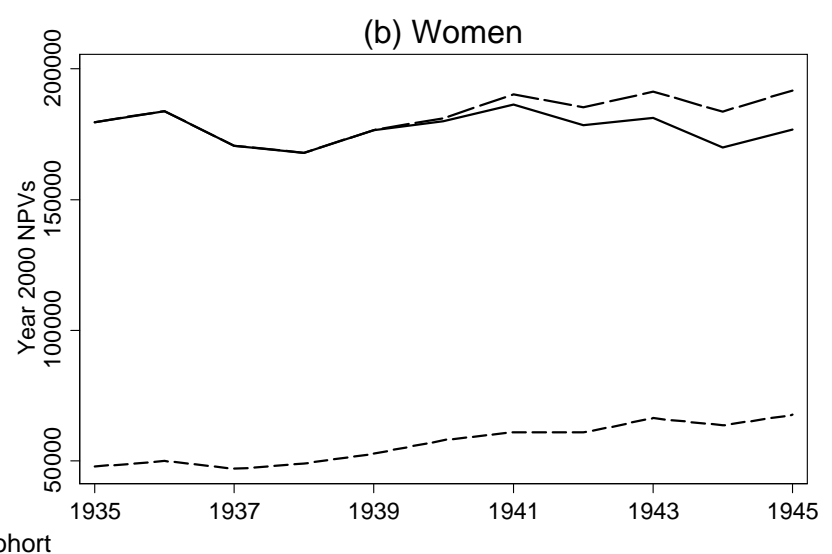

- Pensions with deductions $\quad---$ Pensions w/o deductions

Source: SUFVSKT2002, 2004-2009, own calculations.

The monthly contributions are determined by the contribution rate and the contribution ceiling. The contribution rate is the income share paid to the statutory pension insurance. The contribution ceiling depicts the maximum amount to be paid. Multiplying both rate and ceiling yields the line of maximal contributions. Figure 6 shows their development over the considered time frame. While workers in 1949 had to pay only 10\% of their income up to a ceiling of 14,101 (max. contr.: 1,410€) in year 2000 values, they had to pay $18 \%$ of $41,515 €$ (max. contr.: 7,473€) in 1979 and $19.9 \%$ of

\footnotetext{
${ }^{23}$ E.g. live expectancy of men grew from 17.39 (cohort 1935) to 18.11 years (cohort 1945) after 65 (Federal Statistical Office, 2011).
} 
$56,140 €$ (max contr.: $11,172 €$ ) in 2009 . This corresponds to a quadrupling of the contribution ceiling, a doubling of the rate and an eightfold increase of the maximal contributions over the considered timeframe. Further one-time payments, like Christmas money, became subject to social security contributions beginning in 1984, expanding the contribution base. ${ }^{24}$ At the same time, the average social security wage approximately quadruplet.

Figure 6: Contribution ceiling, average wage and rate of contributions from 1949 to 2013
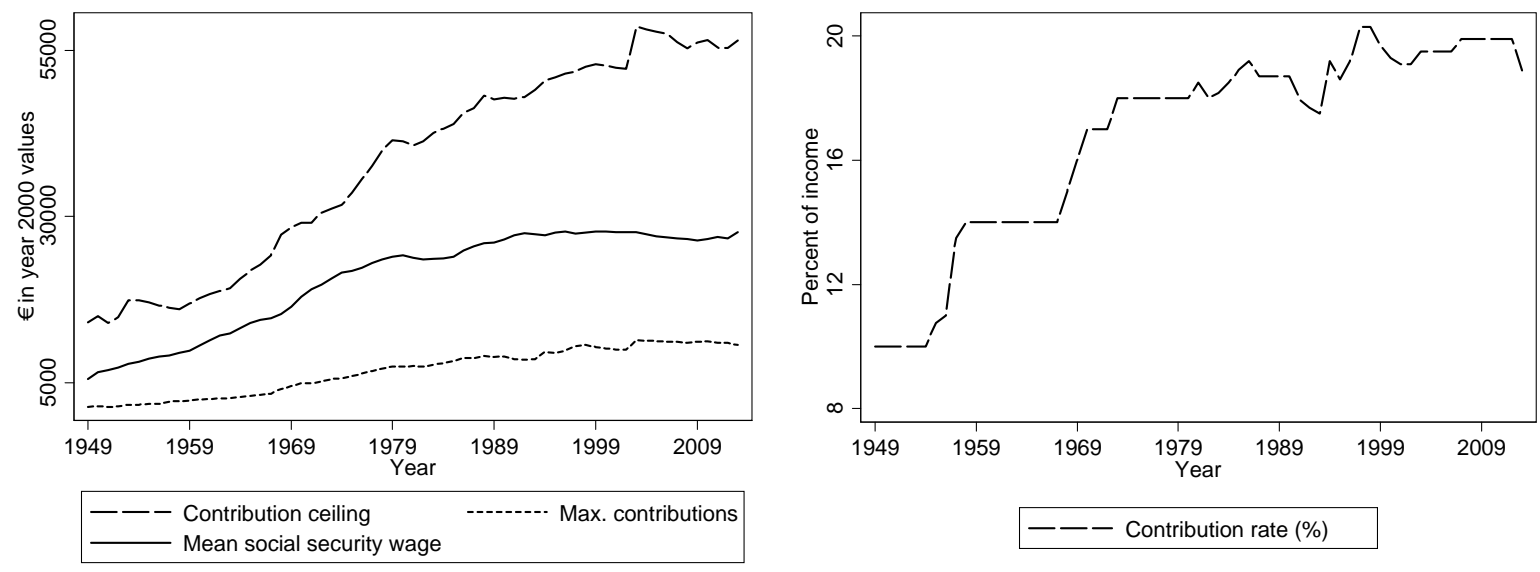

Source: DRV (2013), own calculations.

The increases have greater effects on younger cohorts. To get more insight, Figure 7 displays the average contributions of selected cohorts over the life-cycle. Figure 7(a) and 7(c) show the development of the average contributions in year 2000 real values over time for men and women. While the cohort's mean contributions start apart from each other, they get close in the early 1970's. The movement stays close until shortly before the respective retirement. On the contrary, Figure $7(b)$ and 7 (d) reveal that while starting at about the same level of contributions, the younger cohorts face a higher real contribution burden from age 25 until retirement. Figures 7 and 5 also reveal that men contribute on average about three times as much as women.

\footnotetext{
${ }^{24}$ This causes a structural break in administrative data covering earnings. The break is so pronounced that it is usually adjusted for in studies analyzing earnings inequality before and after 1984 (see Dustmann et al. (2009) for administrative employer data and Bönke et al. (2013) for administrative pension data).
} 
Figure 7: Mean life-cycle contributions in year 2000 real values by sex and cohort

(a) Year (men)

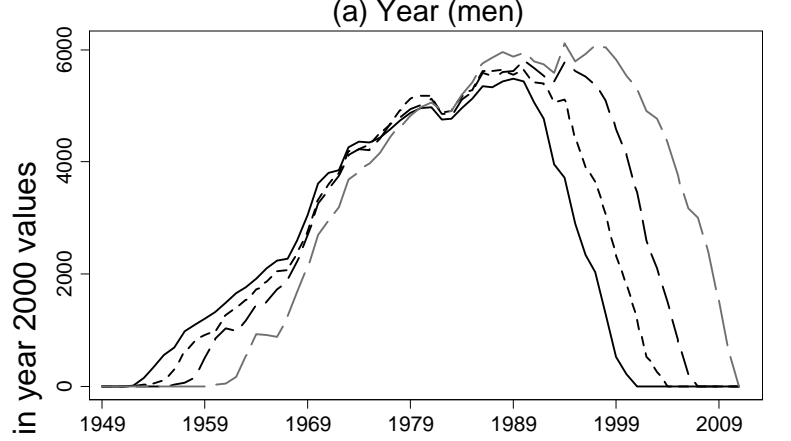

(c) Year (women)

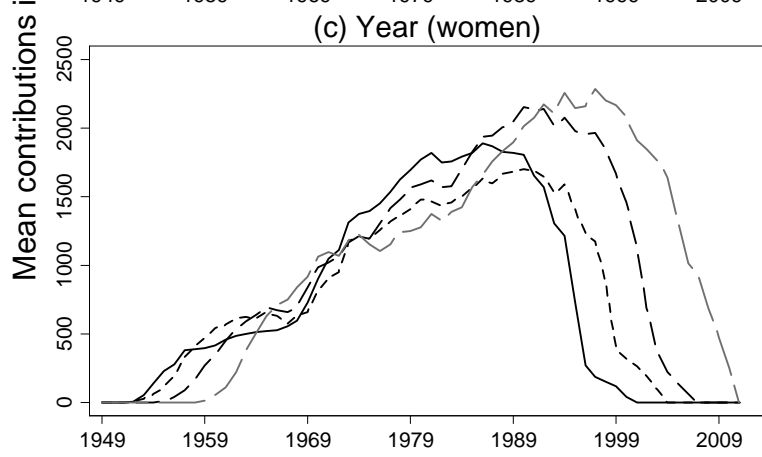

(b) Age (men)

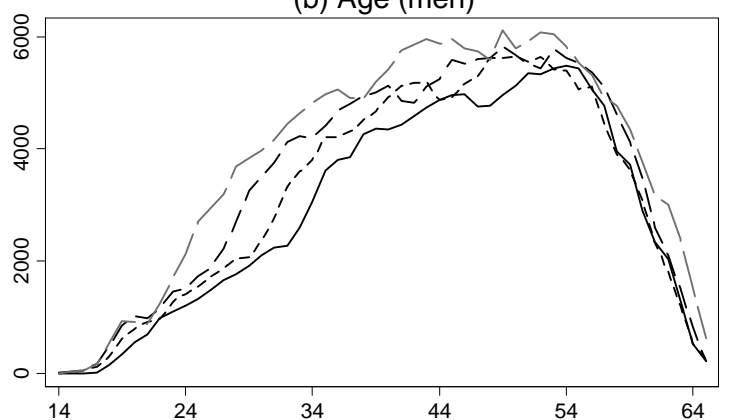

(d) Age (women)

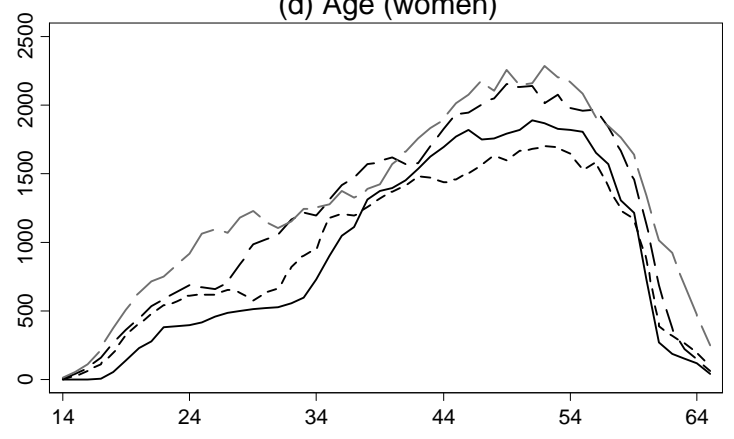

Cohort

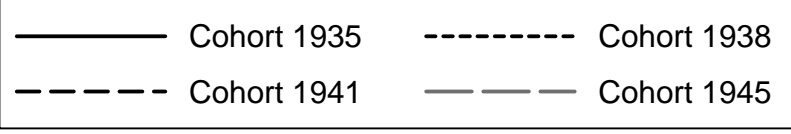

Source: SUFVSKT2002, 2004-2011, own calculations.

Apart from pensions and contributions, the "indirect costs" of the pension system have risen from about 20\% in the 1960s to about 30\% since 2003 (DRV, 2013, own calculations). As "indirect costs" I render the expenditure share of the pension insurance financed by government subsidies. These costs cannot be directly linked to contributions, but if they could, the IRR would be lowered for all cohorts.

The IRR of the pension system is oftentimes compared to capital market interest rates (e.g. Schröder, 2011). Such comparison reveals that both men and women would have been better off (on average), if they had invested their contributions in -assumedly approximately risk-free- German Federal Bonds. The interest rate of Federal Bonds since the 1950's exceeds the IRR of the pension system in most years, especially for men. However, the interest rates converge in recent years (see Figure D.1 in Appendix $\mathrm{D}$ for a graphical comparison). Still these comparisons often miss a point: The pension system provides insurance and is not an interest paying investment. It mainly insures against longevity and invalidity, which are risks worth paying an insurance premium for. Still this premium may not become overly high as this causes contributors to engage in avoidance behavior (BörschSupan and Reil-Held, 2001). 


\section{Conclusion}

This paper analyses the development of the IRR for West German retires in the 1935 through 1945 cohorts. For men the IRR declines from 2.4\% for the 1935 cohort to $1.19 \%$ for the 1945 cohort; for women it is from $5.15 \%$ to $3.72 \%$. The downward trend is robust against major changes in the assumptions. The gender difference is mainly caused by the higher share of transfer points for women. Some smaller part is caused by their higher life expectancy and the old-age retirement for women. The IRR of invalidity retirees exceeds the respective cohort average for both sexes.

The analysis takes place against the background of a reform, which gradually introduces permanent deductions for early retirement for cohorts born in 1937 and thereafter. Counterfactual comparisons suggest that the reform induces $19 \%-30 \%$ of the decline for men and $13 \%-20 \%$ of the decline for women. About $75 \%$ of the decline for men and about $81 \%$ of the decline for women seem to originate from increased contributions.

The analysis considers only the direct and not the indirect costs from government subsidies. Further, participants dying before 65 are not included. Both points reduce the IRR. But due to increases in the contribution rate, ceiling and base the IRR -however measured- will decline for future cohorts even without further reforms. Still, the pension system may not be evaluated on an IRR basis only, because it provides an insurance against longevity and disability. The insurance premium may just not become overly high as this has adverse effects on the contributors' base (Börsch-Supan and ReilHeld, 2001). Thus, a declining IRR lowers the acceptance of the system in general, which could cause a downward spiral. In addition, a small IRR increases the old-age poverty risk for subsequent cohorts if private pensions fail to fill this income gap. Therefore close monitoring of the development of the IRR and private pension schemes should be regarded when designing future reforms and are an important task of future research. 


\section{Bibliography}

Bundesministerium der Justiz (BMJ) (2012): Sozialgesetzbuch (SGB) Sechstes Buch (VI). Available online at http://www.gesetze-im-internet.de/bundesrecht/sgb_6/gesamt.pdf (accessed 11 May 2012).

Bönke, T., G. Corneo and H. Lüthen (2015): Lifetime earnings inequality in Germany. Journal of Labor Economics (forthcoming 2015).

Bönke, T., D. Kemptner and H. Lüthen (mimeo): The introduction of disincentives for early retirement and its effect on labor market participation.

Börsch-Supan, A. (1992): Population Aging, Social Security Design and Early Retirement. Journal of Institutional and Theoretical Economics, 148 (4), 533-557.

Börsch-Supan, A. and A. Reil-Held (2001): How Much is Transfer and How Much is Insurance in a Payas-you-go System? The German Case. The Scandinavian Journal of Economics 103(3), 505-524.

Börsch-Supan, A., A. Reil-Held, R. Rodepeter, R. Schnabel and J. Winter (2001): The German Savings Puzzle. Research in Economics 55(1), 15-38.

Börsch-Supan, A. and R. Schnabel (1998): Social security and declining labor-force participation in Germany. American Economic Review 88(2), 173-178.

Bosworth, B., G. Burtless and E. Steuerle (2000): Lifetime Earnings Patterns, the Distribution of Future Social Security Benefits, and the Impact of Pension Reform. Social Security Bulletin 63(4), 74-97.

Breyer, F. and S. Hupfeld (2010): On the Fairness of Early-Retirement Provisions. German Economic Review 11, 60-77.

Corneo, G., M. Keese, and C. Schröder (2009): The Riester Scheme and Private Savings:

An Empirical Analysis based on the German SOEP. Schmollers Jahrbuch 129, 321 - 332.

Deutsche Rentenversicherung Bund (2011): Codeplan FDZ-Biografiedatensatz - VSKT 2009.

Deutsche Rentenversicherung Bund (2012): Sozioökonomische Situation von Personen mit Erwerbsminderung, DRV-Schriften Band 99.

Deutsche Rentenversicherung Bund (2013): Rentenversicherung in Zeitreihen 2013, DRV-Schriften Band 22.

Dustmann, C., J. Ludsteck and U. Schönberg (2009): Revisiting the German Wage Structure. Quarterly Journal of Economics 124(2), 843-881.

EUROPEAN COMMISSION (2006): The 2005 projections of age-related expenditure (2004-50) for the EU-25 Member States: underlying assumptions and projection methodologies. Available online at http://ec.europa.eu/economy finance/publications/publication6502 en.pdf (accessed 3 December 2012).

Federal Statistical Office (2011): Generationensterbetafeln für Deutschland: Modellrechnungen für die Geburtsjahrgänge 1896-2009. Available online at: 
https://www.destatis.de/DE/Publikationen/Thematisch/Bevoelkerung/Bevoelkerungsbewegung/Gen erationssterbetafeln5126101119004.pdf? blob=publicationFile (accessed 11 May 2012).

Federal Statistical Office (2013): Bevölkerung: Bundesländer, Stichtag, Geschlecht, Altersjahre. Available online at: https://www-genesis.destatis.de/genesis/online (accessed 19 August 2013).

Fullerton, D. and G. E. Metcalf (2002): Tax Incidence. In: Auerbach, A. J. and M. Feldstein (ed.): Handbook of Public Economics (4), Elsevier: Amsterdam, 1799-1872.

Gruber, J. (1997): The Incidence of Payroll Taxation: Evidence from Chile. Journal of Labor Economics $15,72-101$.

Gruber, J. and D. A. Wise (Eds.) (2007): Social Security Programs and Retirement around the World: Fiscal Implications of Reform, University of Chicago Press.

Gustman, A. L. and T. L. Steinmeier (2001): How effective is redistribution under the social security benefit formula? Journal of Public Economics 82, 1-28.

Haan, P. and V. Prowse (2014): Longevity, life-cycle behavior and pension reform, Journal of Econometrics 178(P3), 582-601.

Hairault, J.-O., T. Sopraseuth and F. Langot (2010): Distance to Retirement and Older Workers' Employment: The Case for Delaying the Retirement Age. Journal of the European Economic Association 8, 1034-1076.

Hanel, B. (2010): Financial incentives to postpone retirement and further effects on employment Evidence from a natural experiment. Labour Economics 17, 474-486.

Himmelreicher, R. K. and M. Stegmann (2008): New Possibilities for Socio-Economic Research through Longitudinal Data from the Research Data Centre of the German Federal Pension Insurance (FDZ-RV), Schmollers Jahrbuch 128 (4), 647-660.

Laun, T and J. Wallenius (201X): A Life Cycle Model of Health and Retirement: The Case of the Swedish Pension Reform, forthcoming in Journal of Public Economics.

Liebman J. B. (2002): Redistribution in the Current U.S. Social Security System. In: Feldstein, M. and J. B. Liebman (Eds.): The Distributional Aspects of Social Security and Social Security Reform. National Bureau of Economic Research, Inc., 11-48.

Liebman, J. B., E. Luttmer and D. Seif (2009): Labor supply responses to marginal Social Security benefits: evidence from discontinuities. Journal of Public Economics 93, 1208-1223.

Mastrobuoni, G. (2009): Labor supply effects of the recent social security benefit cuts: Empirical estimates using cohort discontinuities. Journal of Public Economics 93, 1224-1233.

Ohsmann, S. and U. Stolz (2004): Entwicklung der Rendite in der gesetzlichen Rentenversicherung. Betrachtungen zur Rendite der aktuellen und künftigen Altersrenten. Die Deutsche Angestelltenversicherung 4(2) , 119-124. 
OECD (2012): Economic Outlook No 91 - June 2012 - Long-term baseline projections. Online Appendix to the Economic Outlook No 91: http://stats.oecd.org/Index.aspx?DataSetCode=EO91 LTB (accessed 3 December 2012).

Riphahn, R. T. (1999): Disability retirement among German men in the 1980s. Industrial and Labor Relations Review 52(4), 628-647.

Saez, E., M. Matsaganis and P. Tsakloglou (2012): Earnings Determination and Taxes: Evidence from a Cohort Based Payroll Tax Reform in Greece. Quarterly Journal of Economics 127(1), 493-533.

Schmähl, W. (2011): Von der Ergänzung der gesetzlichen Rentenversicherung zu deren partiellem Ersatz: Ziele, Entscheidungen sowie sozial- und verteilungspolitische Wirkungen - Zur Entwicklung von der Mitte der 1990er Jahre bis 2009 - . In: Eichendorfer, E., H. Rische and W. Schmähl (ed.): Handbuch der Gesetzlichen Rentenversicherung SGB IV, Luchterhand: Köln, 169-249.

Schnabel, R. (1998): Rates of Return of the German Pay-As-You-Go Pension System. FinanzArchiv 55, 374-399.

Schnabel, R. and A. Ottnad (2008): Gesetzliche und private Altersvorsorge - Risiko und Rendite im Vergleich. Deutsches Institut für Altersvorsorge, Köln.

Schröder, C. (2011): Profitability of pension contributions - evidence from real-life employment biographies. Journal of Pension Economics and Finance 11, 311-336.

Stock, J. H. und D. A. Wise (1990): Pensions, the Option Value of Work, and Retirement. Econometrica, 58 (5), S. 1151-1180.

Shkolnikov, V. M., R. Scholz, D. A. Jdanov, M. Stegmann and H.-M. von Gaudecker (2008): Length of life and the pensions of five million retired German men, European Journal of Public Health 18 (3), 264-269.

Staubli, S. and J. Zweimüller (2013): Does raising the early retirement age increase employment of older workers? Journal of Public Economics 108, 17-32.

Verband Deutscher Rentenversicherungsträger (VDR) (2004): VDR Statistik Rentenzugang des Jahres 2003 einschließlich Rentenwegfall, Rentenänderung/ Änderung des Teilrentenanteils in der deutschen gesetzlichen Rentenversicherung, Band 149, Frankfurt am Main.

Weitzman, M. L. (2001): Gamma Discounting. The American Economic Review 91(1), 260-271. 


\section{Appendix A: Data - Sample selection and retirement type}

\section{A.1 Sample selection}

The estimation procedure can obtain multiple IRR for individuals who shift their status between pensions and contributions (Schröder, 2011), which is true for about 5\% of the individuals in the sample. Those individuals are excluded since they get invalidity pensions for a limited time span, then do something else (e.g. employment, unemployment, mini-jobs) and, subsequently, obtain old-age pensions. Further women with marriage refunds are excluded (about $15 \%$ of the women in the sample). Until 1967 it was legally allowed for women to leave the pension system at the time of their marriage and gain the monetary value of their collected earnings points. Until 1995, however, these women could reenter the pension system through retroactive payments. This arrangement was extremely profitable: The contributions were assigned to earliest possible contribution periods (starting at age 14 or the year 1957) and in nominal values. Consequently those women have extremely high contributions at a very young age, which were paid in later years. Thus only for these women the payment period and the contribution period do not overlap; a comparison to the rest of the sample is not meaningful.

\section{A.2 Retirement type determination}

Determining which of the five possible old-age pensions an individual is receiving is not always unambiguous. If a person qualifies for multiple retirement types, I assign the most beneficial type (see Figure 1 for a ranking):

1. The regular old-age pension is obvious and assigned to all individuals retiring after their $65^{\text {th }}$ birthday.

2. The pension for long-term insured is assigned to all persons retiring between their $63^{\text {rd }}$ and their $65^{\text {th }}$ birthday, if they fulfill the waiting period of 35 years.

3. Disability pensions are ascribed to individuals who formerly received invalidity pensions or sick-pay after the age of 59 for at least one month. Sick-pay is paid by the health insurance after being unable to work for three month in a row. I assume that both sick-pay and invalidity pensions shortly before retirement sufficiently indicate a disablement.

4. Unemployment pensions are assigned to persons who are unemployed for at least 12 months after being 58.5 years old. Unemployment pensions are also given to persons who do not qualify for other pensions, assuming a retirement due to the law about part-time work for employees over 55 . About $10 \%$ of the men (and a negligible amount of women) in the sample do not qualify for any pension with the approaches discussed above. Of those men nearly all (96\%) retire before the age of 63 , making them eligible only for unemployment or disability retirement. This leads to an imprecision between these two kinds of pension, because some of these males might actually retire with a disability pension.

5. The old-age pension for women is assigned to women who have accumulated at least 120 months of compulsory contributions after their $40^{\text {th }}$ birthday.

In case of invalidity pensions, there is no way of distinguishing between full and partial invalidity in the sample. Following e.g. Riphahn (1999), the full pension is assigned to all invalidity pension recipients. This results in an overestimation of the invalidity pensions for about $20 \%$ of the recipients. For the great majority the overestimation amounts to $1 / 3$ of the pension amount, because invalidity 
pensions initially received before 2001 are treated according to the pre-reform state. In the final sample $13.55 \%$ of men and $10.43 \%$ of women received invalidity pensions. The annual level of invalidity pensions is approximated by accumulating the entire credited earnings points ${ }^{25}$ up to the respective year and multiplying them with the pension value and the number of months the pension is received in the respective year.

\section{A.3 Exemplary descriptive statistics on retirement types}

Figure A.1: Male old-age retirement shares by pension type in the year 2003 (official and sample)

(a) Official

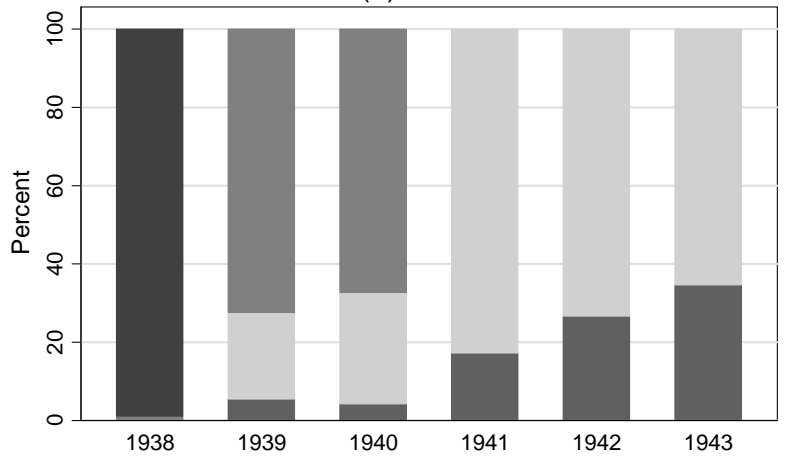

(b) Sample

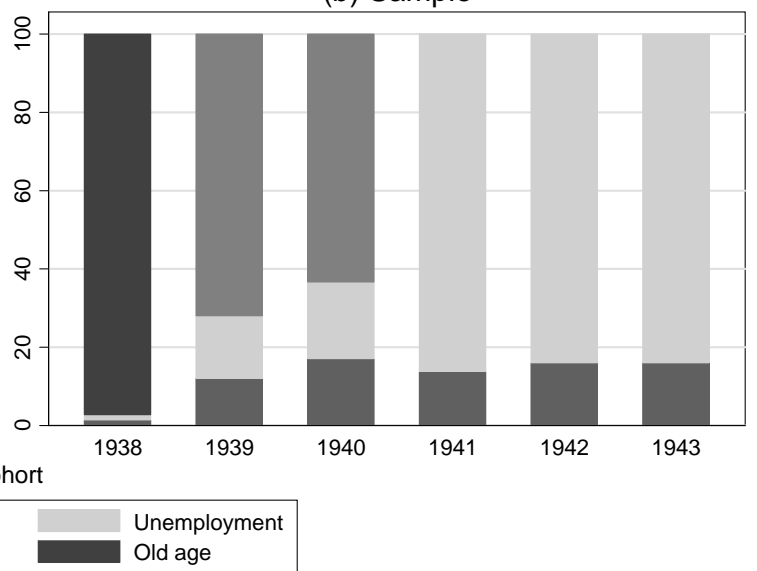

Note: The cohorts represent a different age; cohort 1938 represents age 65, cohort 1939 age 64 etc. Source: VDR (2004) [Official] and SUFVSKT2002, 2004-2011 [Sample], own calculations.

Figure A.1 shows the retirement type for different male cohorts in the exemplary year 2003. Figure A.1 compares the observed values (right panel) to the actual values from the pension statistics (left panel). Regular old-age pensions are depicted correctly in the data. Also the sample shares of longterm insured for the cohorts 1939 and 1940 (age 64 and 63) match the actual data quite well. The sample shares for unemployment and disability pension show some deviations, which could result from a partial mix up between unemployment and disability pensions. Details for the retirement by cohort and retirement type in the year 2003 are provided in Table A.1-A.4. The comparison between the sample and the actual shares reveals a reasonable fit. Still the low number of observations in some cells potentially causes deviations from the actual values, which is especially true for women: In 2003 over $90 \%$ of the women in the sample retire either through the old-age retirement for women or the regular old-age pension, making Figure A.1 superfluous for women.

\footnotetext{
${ }^{25}$ The entire credited earnings points consist of earnings points from social security employment and transfer points (see Section 2.5 for details).
} 
Table A.1: Number and share of men retiring in 2003 by cohort (old-age pensions only)

\begin{tabular}{|c|c|c|c|c|c|}
\hline Age & Cohort & $\begin{array}{c}\text { Observations } \\
\text { (unweighted) }\end{array}$ & $\begin{array}{c}\text { Observations } \\
\text { (weighted) }\end{array}$ & $\begin{array}{c}\text { Sample share } \\
\text { (weighted) }\end{array}$ & Actual share \\
\hline 60 & 1938 & 75 & 68,701 & 32.22 & 31.63 \\
61 & 1939 & 25 & 23,246 & 10.9 & 4.44 \\
62 & 1940 & 41 & 40,211 & 18.86 & 23.27 \\
63 & 1941 & 29 & 25,404 & 11.91 & 8.92 \\
64 & 1942 & 25 & 17,317 & 8.12 & 9.64 \\
65 & 1943 & 50 & 35,871 & 16.82 & 22.11 \\
\hline
\end{tabular}

Note: The cohorts represent a different age as indicated in the first two columns.

Source: VDR (2004) [Actual] and SUFVSKT2002, 2004-2011 [Sample], own calculations.

Table A.2: Number and share of woman retiring in 2003 by cohort (old-age pensions only)

\begin{tabular}{|c|c|c|c|c|c|}
\hline Age & Cohort & $\begin{array}{c}\text { Observations } \\
\text { (unweighted) }\end{array}$ & $\begin{array}{c}\text { Observations } \\
\text { (weighted) }\end{array}$ & $\begin{array}{c}\text { Sample share } \\
\text { (weighted) }\end{array}$ & Actual share \\
\hline 60 & 1938 & 165 & 95,397 & 45.51 & 45.28 \\
61 & 1939 & 10 & 6,049 & 2.89 & 1.27 \\
62 & 1940 & 19 & 11,792 & 5.63 & 4.48 \\
63 & 1941 & 49 & 32,136 & 15.33 & 4.41 \\
64 & 1942 & 27 & 15,448 & 7.37 & 12.61 \\
65 & 1943 & 82 & 41,736 & 19.91 & 31.96 \\
\hline
\end{tabular}

Note: The cohorts represent a different age as indicated in the first two columns.

Source: VDR (2004) [Actual] and SUFVSKT2002, 2004-2009 [Sample], own calculations.

Table A.3: Number and share of men retiring in 2003 by retirement type (old-age pensions only)

\begin{tabular}{|c|c|c|c|c|}
\hline Retirement type & $\begin{array}{c}\text { Observations } \\
\text { (unweighted) }\end{array}$ & $\begin{array}{c}\text { Observations } \\
\text { (weighted) }\end{array}$ & $\begin{array}{c}\text { Sample share } \\
\text { (weighted) }\end{array}$ & Actual share \\
\hline Disability & 27 & 22,323 & 10.47 & 12.64 \\
Unemployment & 101 & 79,311 & 37.19 & 35.60 \\
Longterm insured & 44 & 42,129 & 19.76 & 18.69 \\
Old-age & 76 & 69,472 & 32.58 & 33.01 \\
\hline
\end{tabular}

Source: VDR (2004) [Actual] and SUFVSKT2002, 2004-2011 [Sample], own calculations.

Table A.4: Number and share of women retiring in 2003 by retirement type (old-age pensions only)

\begin{tabular}{|c|c|c|c|c|}
\hline Retirement type & $\begin{array}{c}\text { Observations } \\
\text { (unweighted) }\end{array}$ & $\begin{array}{c}\text { Observations } \\
\text { (weighted) }\end{array}$ & $\begin{array}{c}\text { Sample share } \\
\text { (weighted) }\end{array}$ & Actual share \\
\hline Disability & 22 & 11,110 & 5.3 & 0.89 \\
Unemployment & 7 & 4,266 & 2.04 & 5.46 \\
Longterm insured & 1 & 900 & 0.43 & 2.46 \\
Old-age & 117 & 65,779 & 31.38 & 45.19 \\
Women & 219 & 127,557 & 60.85 & 46.00 \\
\hline
\end{tabular}

Source: VDR (2004) [Actual] and SUFVSKT2002, 2004-2011 [Sample], own calculations 


\section{Appendix B: Number of observations and IRR by Scenario}

Table B.1: Number of unweighted observations by Scenario (women)

\begin{tabular}{|c|cccc|}
\hline & $\begin{array}{c}\text { Scenario 1 } \\
\text { (base) }\end{array}$ & $\begin{array}{c}\text { Scenario 2 } \\
\text { (invalidity) }\end{array}$ & $\begin{array}{c}\text { Scenario 3 } \\
\text { (complete) }\end{array}$ & $\begin{array}{c}\text { Scenario 4 } \\
\text { (no invalidity) }\end{array}$ \\
\hline 1935 & 359 & 45 & 137 & 314 \\
1936 & 367 & 50 & 143 & 317 \\
1937 & 386 & 46 & 149 & 340 \\
1938 & 341 & 41 & 118 & 300 \\
1939 & 345 & 36 & 140 & 309 \\
1940 & 368 & 32 & 161 & 336 \\
1941 & 373 & 42 & 163 & 331 \\
1942 & 370 & 39 & 150 & 331 \\
1943 & 369 & 35 & 154 & 334 \\
1944 & 388 & 24 & 165 & 364 \\
1945 & 389 & 33 & 157 & 356 \\
\hline Overall & 4,055 & 423 & 1637 & 3632 \\
\hline
\end{tabular}

Note: Scenario (1) [base] allows up to 300 month of missing information between 30 and 60 . Scenario (2) [invalidity] only considers persons with invalidity pensions. Scenario (3) [complete] restricts on no missing information between 30 and 60. Scenario (4) [no invalidity] excludes persons with invalidity pensions.

Source: SUFVSKT2002, 2004-2011, own calculations.

Table B.2: Number of unweighted observations by Scenario (men)

\begin{tabular}{|c|cccc|}
\hline & $\begin{array}{c}\text { Scenario 1 } \\
\text { (base) }\end{array}$ & $\begin{array}{c}\text { Scenario 2 } \\
\text { (invalidity) }\end{array}$ & $\begin{array}{c}\text { Scenario 3 } \\
\text { (complete) }\end{array}$ & $\begin{array}{c}\text { Scenario 4 } \\
\text { (invalidity) }\end{array}$ \\
\hline 1935 & 260 & 40 & 204 & 220 \\
1936 & 262 & 44 & 205 & 218 \\
1937 & 257 & 43 & 199 & 214 \\
1938 & 254 & 47 & 196 & 207 \\
1939 & 293 & 43 & 232 & 250 \\
1940 & 262 & 29 & 215 & 233 \\
1941 & 278 & 30 & 221 & 248 \\
1942 & 262 & 38 & 203 & 224 \\
1943 & 252 & 31 & 196 & 221 \\
1944 & 252 & 24 & 197 & 228 \\
1945 & 269 & 24 & 215 & 245 \\
\hline Overall & 2,901 & 393 & 2283 & 2508 \\
\hline
\end{tabular}

Note: Scenario (1) [base] allows up to 300 month of missing information between 30 and 60. Scenario (2) [invalidity] only considers persons with invalidity pensions. Scenario (3) [complete] restricts on no missing information between 30 and 60. Scenario (4) [no invalidity] excludes persons with invalidity pensions.

Source: SUFVSKT2002, 2004-2011, own calculations. 
Figure B.1: Means of the IRR by cohort and sex for Scenario 1 (base), Scenario 3 (complete) and Scenario 4 (no invalidity) with baseline assumptions and the assumption of constant pensions

(a) Men: Base

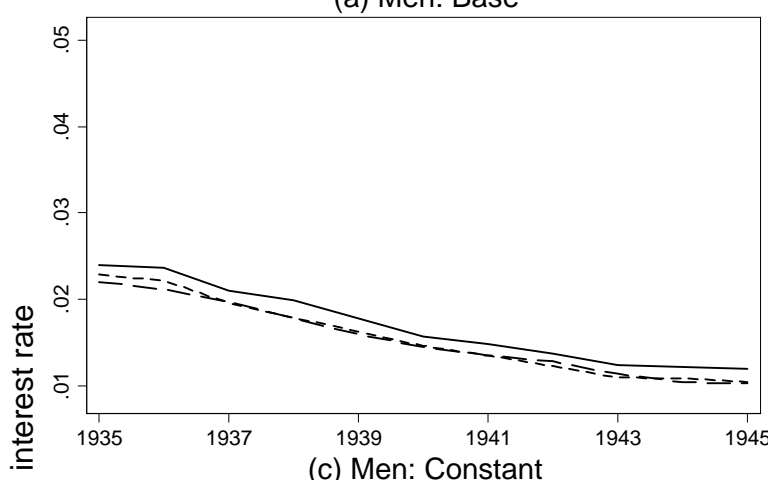

(c) Men: Constant

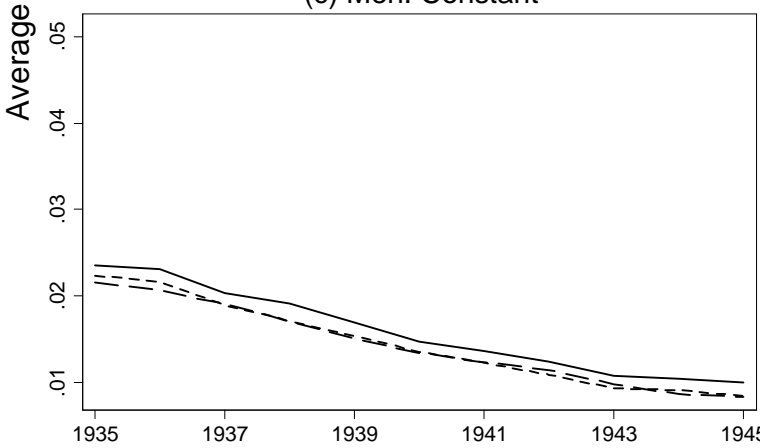

(b) Women: Base

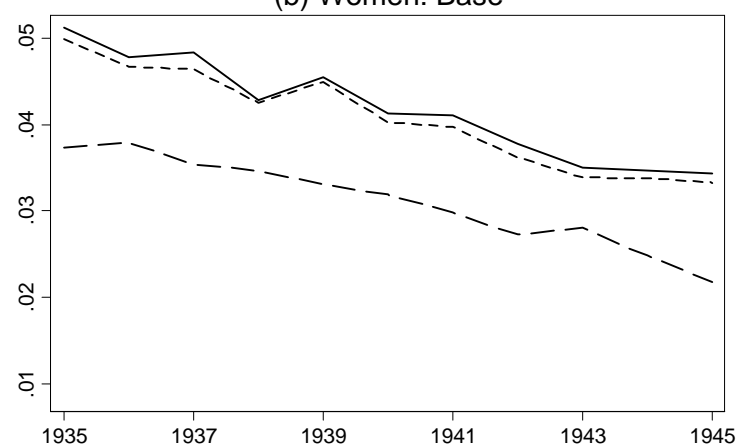

(d) Women: Constant

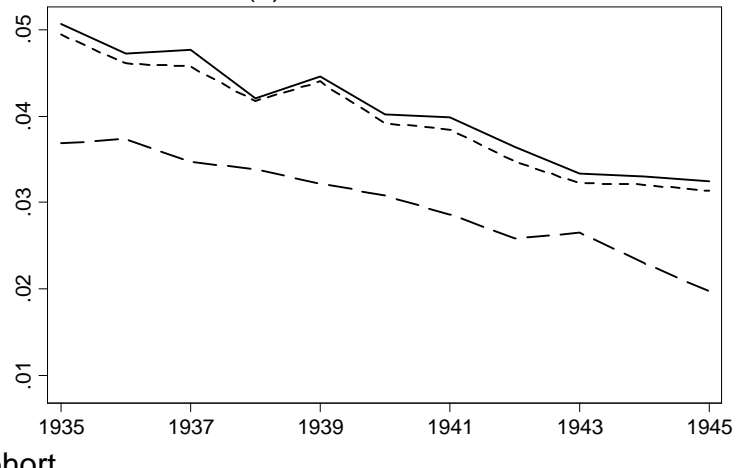

Cohort

Note: Scenario (1) [base] allows up to 300 month of missing information between 30 and 60. Scenario (3) [complete] restricts on no missing information between 30 and 60. Scenario (4) [no invalidity] excludes persons with invalidity pensions. The scenarios are calculated under the baseline assumptions [panel (a) and panel (b)] or under the assumption of a constant pension [panel (c) and (d)].

Source: SUFVSKT2002, 2004-2011, own calculations. 


\section{Appendix C: Robustness}

Figures C.1-C.3 indicate that the discovered trend is stable over various assumptions made in the paper. While all robustness tests shift the level, the trend is only slightly affected. Disregarding employer benefits increases the IRR by about 2.4 percentage points for both sexes. Disregarding divorces increases the IRR for men by about 0.07 percentage points and lowers the IRR for women by about 0.1 percentage points (men give more earnings points to women than they receive). For the differential mortality results, I first divide the men in the sample in quintiles (before excluding any persons) and then adjust their mortality rate with mortality ratios between quintiles drawn from Shkolnikov et al. (2007). ${ }^{26}$ This mortality adjustment favors persons with high pensions and leads to an increase of 0.1 percentage points for men. Unfortunately, no results are available for women.

Figure C.1: Robustness tests of the IRR, means by gender and cohort

(a) Robustness (men)

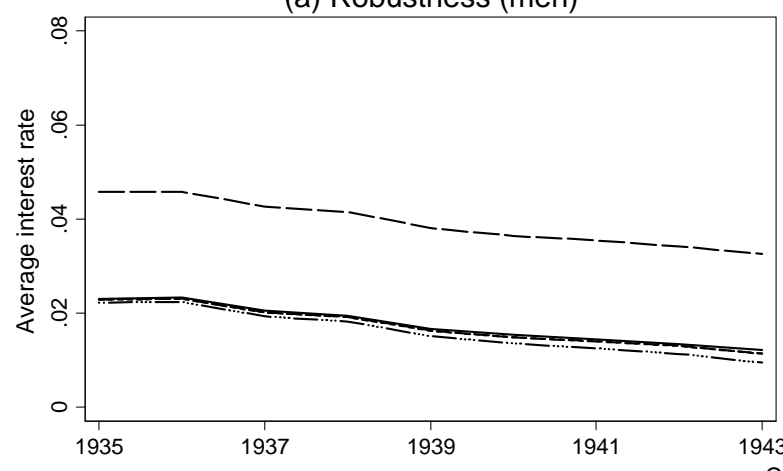

(b) Robustness (women)

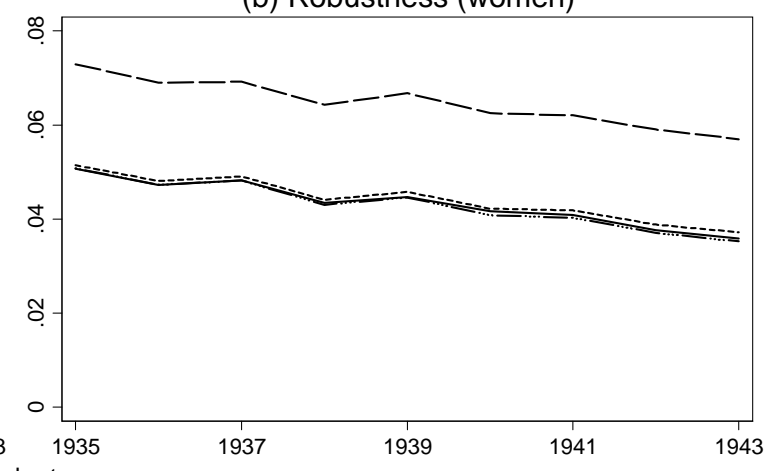
Cohort

--- Employee contr. only $\quad-----$ Differential mortality
$-\ldots-\cdots-$ Constant

Source: SUFVSKT2002, 2004-2011, own calculations.

Figure C.2 shows results for varying marriage rates $\left(m_{v}=0\right.$ or 1$)$ and compares it those obtained from the SOEP. The trends are stable again. For men a rate of 0 results in an IRR loss of about 0.1 percentage points and a rate of 1 in a gain of about 0.08 . For women the effects are much larger as they are both more likely to receive survivor benefits and also receive a greater amount. Here a rate of 0 results in a drop of about 0.6 percentage points and a rate of 1 in a gain of about 0.2.

Figure C.2: IRR for varying marriage rates, means by gender and cohort

\footnotetext{
${ }^{26}$ The study of Shkolnikov et al. (2007) is based on administrative pension data. Other mortality rates cannot be applied because of missing information on earnings apart from social security earnings. This causes the mortality curve of administrative pension data to be j-shaped instead of increasing in the number of collected earnings points: Persons in the lowest quintile often draw income from other sources than social security employment, causing them to do better (income wise) than the second quintile.
} 
(a) Widower pensions

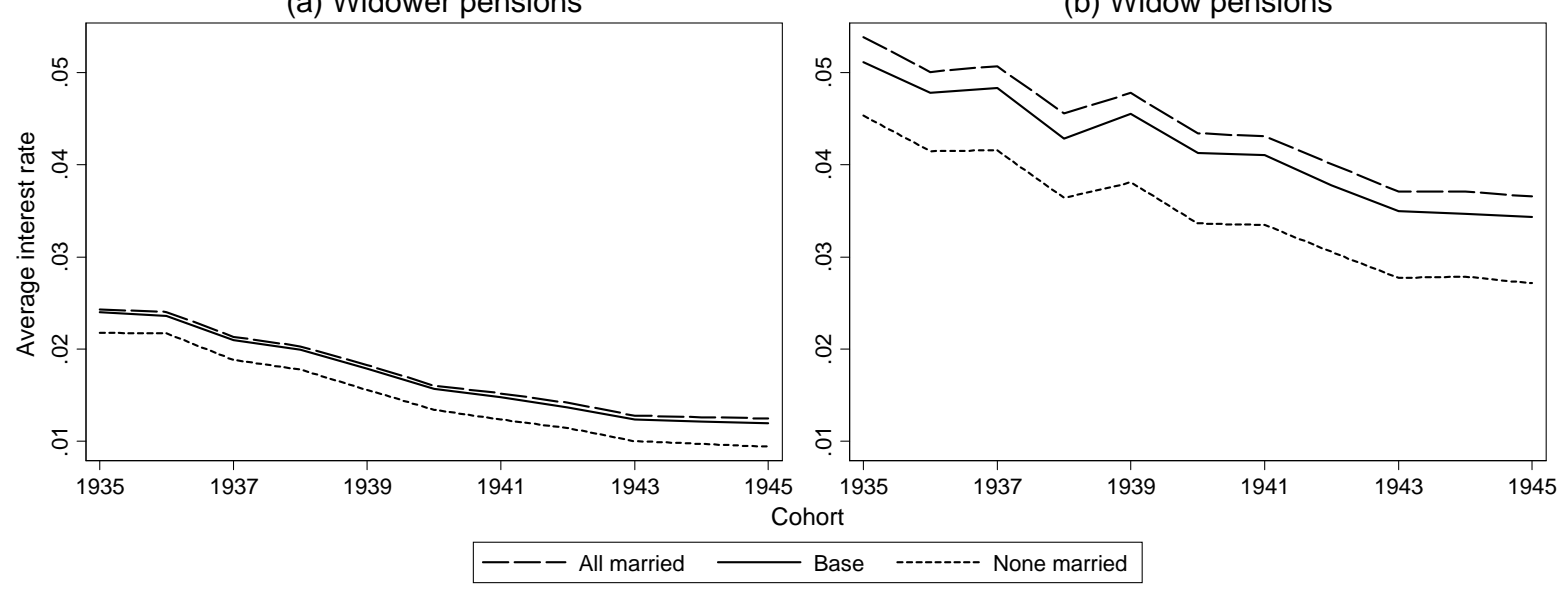

Source: SUFVSKT2002, 2004-2011, own calculations.

Figure C.3 shows the IRR of cohort and year specific means in comparison to the baseline estimation. The cohort specific means are drawn with jackknife, which always excludes one observation and then calculates the mean. This creates as many means as there are observations in the underlying sample. Those are used in the estimation procedure described above. The IRR of the cohort means are 0.05 (men) and about 0.6 (women) percentage points lower than the baseline estimates. The differences are significant at the $95 \%$ level for women, confirming Figure 3 with a greater spread in the IRR of women.

Figure C.3: IRR of gender- and cohort-specific means

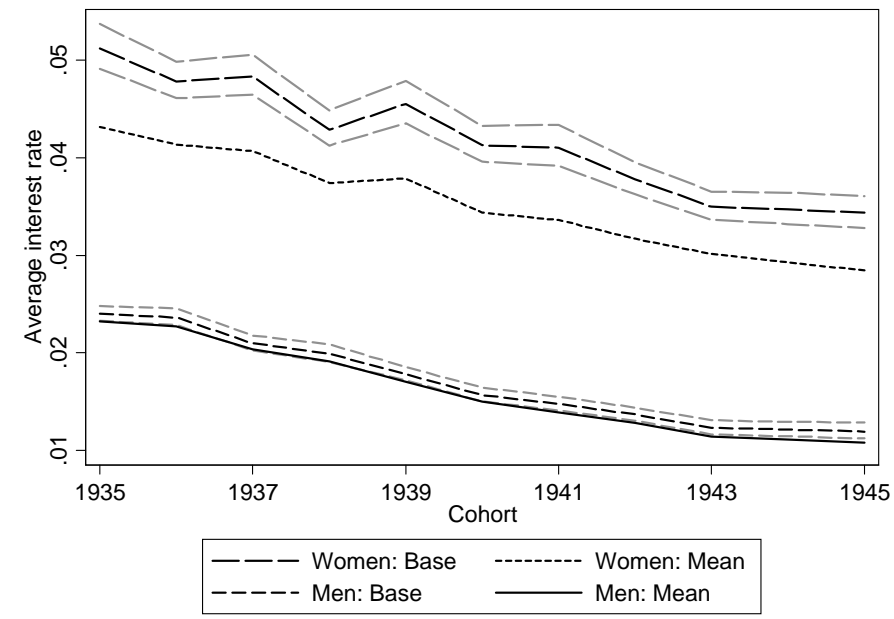

Source: SUFVSKT2002, 2004-2011, own calculations.

Annotation: The grey lines indicate 95\% confidence intervals. The confidence intervals of "Women: Mean" and "Men: Mean" are suppressed because they lie visually on top of the IRR estimation. 


\section{Appendix D: Supplementary graphics}

Figure D.1: Growth factors of pension values and the CPI and interest rates of federal bonds 19572013

(a) Growth factor

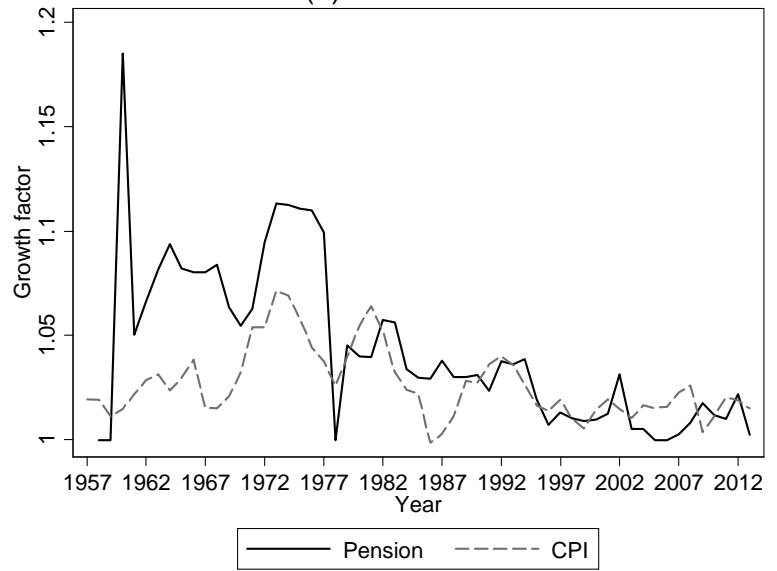

(b) Interest factor

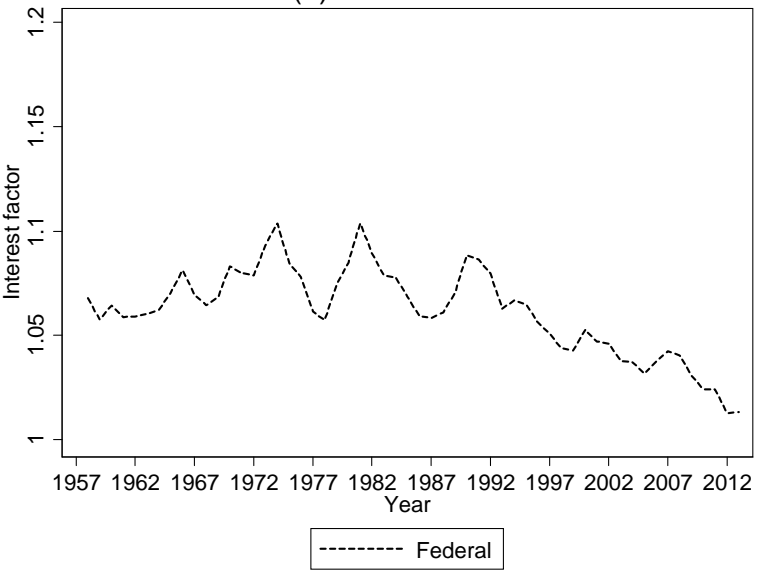

Source: DRV (2013), own calculations. The interest factor time series and details on its methodology can be found at http://www.bundesbank.de/statistik/statistik zeitreihen.php?lang=de\&open=zinsen\&func=row\&tr=WU0004 